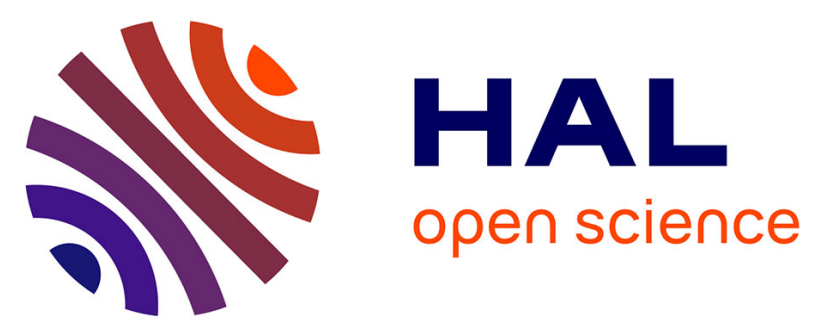

\title{
Reconstructing Species Relationships within the Recently Diversified Genus Odontites Ludw. (Orobanchaceae): Evidence for Extensive Reticulate Evolution
}

Myriam Gaudeul, Sonia Siljak-Yakovlev, Tae-Soo Jang, Germinal Rouhan

\section{To cite this version:}

Myriam Gaudeul, Sonia Siljak-Yakovlev, Tae-Soo Jang, Germinal Rouhan. Reconstructing Species Relationships within the Recently Diversified Genus Odontites Ludw. (Orobanchaceae): Evidence for Extensive Reticulate Evolution. International Journal of Plant Sciences, 2018, 179 (1), pp.1-20. 10.1086/694763 . mnhn-02975274

\section{HAL Id: mnhn-02975274}

\section{https://hal-mnhn.archives-ouvertes.fr/mnhn-02975274}

Submitted on 22 Oct 2020

HAL is a multi-disciplinary open access archive for the deposit and dissemination of scientific research documents, whether they are published or not. The documents may come from teaching and research institutions in France or abroad, or from public or private research centers.
L'archive ouverte pluridisciplinaire $\mathbf{H A L}$, est destinée au dépôt et à la diffusion de documents scientifiques de niveau recherche, publiés ou non, émanant des établissements d'enseignement et de recherche français ou étrangers, des laboratoires publics ou privés. 


\title{
RECONSTRUCTING SPECIES RELATIONSHIPS WITHIN THE RECENTLY DIVERSIFIED GENUS ODONTITES LUDW. (OROBANCHACEAE): EVIDENCE FOR EXTENSIVE RETICULATE EVOLUTION
}

\author{
Myriam Gaudeul, ${ }^{1, *}$ Sonja Siljak-Yakovlev, † Tae-Soo Jang, $\neq$ and Germinal Rouhan* \\ *Institut de Systématique, Évolution, Biodiversité, Unité Mixte de Recherche 7205, Centre National de la Recherche Scientifique (CNRS), \\ Université Pierre et Marie Curie, École Pratique des Hautes Études, Muséum National d'Histoire Naturelle, Sorbonne Universités, \\ 57 rue Cuvier, CP39, F-75005 Paris, France; +Laboratoire Ecologie, Systématique, et Evolution, Unité Mixte de Recherche 8079 , \\ Université Paris-Sud-CNRS-AgroParisTech, Université Paris-XI, Bâtiment 360, F-91405 Orsay, France; and ¥Department of \\ Systematic and Evolutionary Botany, Institute of Botany, University of Vienna, Rennweg 14, A-1030 Vienna, Austria
}

Editor: Félix Forest

\begin{abstract}
Premise of research. Odontites is an herbaceous genus composed of 27 species, mostly distributed around the Mediterranean Basin. As a first step toward studying species diversification within this genus, our goals were to (i) test previous hypotheses about phylogenetic relationships among species; (ii) assess whether the closely related genera Bartsiella, Bornmuellerantha, Macrosyringion, and Odontitella should be included in Odontites; and (iii) detect potential events of reticulate evolution.
\end{abstract}

Methodology. We estimated phylogenetic relationships based on nuclear (ITS and ETS) and chloroplast ( $p s b \mathrm{~A}-t r n \mathrm{H}, \operatorname{trn} \mathrm{C}-y c f 6$, and $\operatorname{trn} \mathrm{L}-\operatorname{trn} \mathrm{F}$ ) DNA regions. Our sampling included 184 individuals representing 25 out of the 27 species of Odontites. We also counted chromosomes in five species and measured nuclear genome sizes in 139 individuals of 21 species.

Pivotal results. We showed that Bartsiella and Bornmuellerantha should be returned to Odontites, while Odontitella was confirmed as distinct. Macrosyringion requires further investigations. Several phylogenetic incongruences were identified, suggesting two cases of hybrid speciation (in O. maroccanus and O. violaceus) and several introgression events. These events were very diverse in terms of number of individuals involved, species co-occurrence, direction of introgression, and incidence of genome doubling. We obtained new chromosome numbers for O. hispidulus $(2 \mathrm{n}=4 \mathrm{x}=40)$ and $O$. powellii $(2 \mathrm{n}=2 \mathrm{x}=20)$, and no relation between nuclear genome size and chromosome number was found.

Conclusions. We inferred hybrid speciation and various introgression events, and polyploidy was also detected. Odontites appears as an interesting genus to study species diversification, providing a group of closely related species that display, e.g., morphological, ecological, or phenological character variation; cases of study at different temporal stages in the diversification process; and several contact zones between species.

Keywords: hybridization, introgression, molecular phylogeny, Odontites, reticulate evolution, systematics.

\section{Introduction}

A major field of evolutionary research is the study of species diversification: why and how do new species emerge? What are the evolutionary forces involved and the mechanisms leading to new, evolutionarily independent, and reproductively isolated species? Two forces that are commonly involved in speciation are genetic drift and diversifying selection (for a review, see, e.g., Marie Curie SPECIATION Network 2012). In plants, hybridization and polyploidization have also been shown to be crucial sources of new species (Rieseberg 1997; Mallet 2007; Soltis and Soltis 2009; Abbott et al. 2013). Hybrids combine

${ }^{1}$ Author for correspondence; e-mail: gaudeul@mnhn.fr.

Manuscript received April 2017; revised manuscript received July 2017; electronically published November 15, 2017. the genomes and allelic diversity of their two parents, which may increase fitness, facilitate adaptation, result in different and larger ecological amplitudes compared to the progenitor species, allow installation in novel habitats, and ensure high evolutionary success (Seehausen 2004; Mallet 2007; Abbott et al. 2013). Hybridization can be accompanied by an increase in ploidy level (polyploid hybridization) or not (homoploid hybridization). In turn, polyploidization can occur without hybridization, i.e., following a cross among individuals within a species (autopolyploidy) or following a hybridization event (allopolyploidy; Weiss-Schneeweiss et al. 2013). Polyploidization is thought to favor the speciation process, because polyploids tend to be reproductively isolated from their parents (Seehausen 2004; Mallet 2007; Soltis and Soltis 2009; Nolte and Tautz 2010; Abbott et al. 2013). Polyploidization has long been recognized as widespread in plants, and ca. $30 \%$ of extant angio- 
sperm species are estimated to have undergone polyploidization since their genus arose (Wood et al. 2009; Escudero et al. 2014).

Gene flow can also take place between two existing species without leading to the formation of a third species, because of subsequent backcrossing with parental species. This phenomenon, called introgression, results in the transfer of genetic material between species (Soltis and Soltis 2009; Nolte and Tautz 2010). It can therefore slow down the process of ongoing diversification and blur the phylogenetic relationships between species. In the absence of a significant selective advantage and if introgression occurs only as an unusual, chance event, the genome of the introgressed individual(s) will progressively homogenize with one of the parental species, and the introgressed form will ultimately disappear. However, such introgressions also represent a potential first step toward hybrid speciation through the formation of hybrid zones and hybrid swarms (Nolte and Tautz 2010).

The Mediterranean region provides a variety of plant groups and evolutionary histories and a promising background to study plant diversification. Indeed, as a result of its complex geological history and mosaic landscape (notably including several island systems), the Mediterranean Basin is characterized by a very high species richness that is at least partly explained by high rates of diversification (Thompson 2005; Valente et al. 2010).

The genus Odontites Ludw. comprises 27 hemiparasitic, usually herbaceous and annual species (Bolliger 1996; Crespo and Mateo Sanz 2009). Species are distributed along both the northern and the southern shores of the Mediterranean Sea, on islands such as Corsica and Sicily, and some of them extend northward up to Scandinavia, westward to the island of Madeira, and eastward to the Himalayas. Species differ by their distribution range (from widely distributed to microendemics) and display a variety of morphological, phenological, and life-history traits, such as flowering time (spring vs. autumn; fig. 1; illustrations in Bolliger 1996). A previous study based on chloroplast DNA sequencing and phylogenetic reconstructions showed that the genus diversified recently (mostly <10 Ma; Gaudeul et al. 2016), probably explaining the low resolution in some clades. Such a low resolution may also be due to reticulate evolution, which was previously suggested in Odontites based on morphology and karyology: O. vernus has been hypothesized to be an autotetraploid of O. vulgaris, while O. jaubertianus was thought to be an allotetraploid of O. vulgaris and O. luteus (Bolliger 1996 and references therein). The reconstruction of both plastid- and nuclear-based phylogenetic relationships sometimes allows the identification of incongruent patterns among them, which can suggest reticulate events (Linder and Rieseberg 2004; Seehausen 2004; Vriesendorp and Bakker 2005 and references therein; Soltis et al. 2008; for examples, see also, e.g., Frajman and Oxelman 2007; Yi et al. 2008; Wu et al. 2015). Another explanation for such incongruences is incomplete lineage sorting of ancestral polymorphisms, and it is often difficult to discriminate between reticulate evolution and incomplete lineage sorting based on DNA sequences (see, e.g., Van der Niet and Linder 2008; Blanco-Pastor et al. 2012). In Odontites, some ambiguities also remain on the circumscription of the genus and the inclusion of four closely related genera that were recently segregated from Odontites based on morphology (Bolliger 1996): Bartsiella Bolliger, Bornmuellerantha Rothm., Macrosyringion Rothm., and Odontitella Rothm. These four genera count a to- tal of six species (Bolliger 1996; Dönmez and Mutlu 2010). Previous phylogenetic investigations focused on the Rhinantheae tribe (Tesitel et al. 2010; Scheunert et al. 2012) but included only a few Odontites species (at most, six out of 27 in Scheunert et al. 2012). Scheunert et al. (2012) and Gaudeul et al. (2016) suggested the need to consider a broadly circumscribed Odontites s.l. genus, including Bartsiella and Bornmuellerantha (as also shown by Tesitel et al. 2010 for the latter one). They confirmed Odontitella as a distinct lineage, whereas the position of Macrosyringion remained ambiguous, with an incongruence between the topologies based on nuclear DNA (nDNA) and chloroplast DNA (cpDNA).

Given the lack of resolution in plastid phylogenies and the existence of taxonomic uncertainties, and as a first step toward understanding the drivers of species diversification within Odontites, our main goals were to (i) test previous hypotheses concerning phylogenetic relationships among species; (ii) assess to what extent the genera Bartsiella, Bornmuellerantha, Macrosyringion, and Odontitella should be included in Odontites; and (iii) detect potential events of reticulate evolution (introgression, hybridization) and/or polyploidization in the genus. Therefore, we inferred species relationships based on both nuclear (ITS and ETS) and plastid (psbA-trnH, $\operatorname{trn} \mathrm{C}-y c f 6$, and $\operatorname{trn} \mathrm{L}-\operatorname{trn} \mathrm{F})$ regions. Because karyological data are missing for 11 out of the 27 Odontites species, we also aimed at obtaining additional data on chromosome counts, ploidy levels, and nuclear genome sizes within the genus. The chromosome number $x=$ 12 was proposed as the basic, haploid chromosome number, and diploid and tetraploid karyotypes have been previously established (Snogerup 1977; Bolliger 1996; Rico et al. 2008; Rico 2009; Delgado et al. 2015).

\section{Material and Methods}

\section{Taxonomic Sampling and Plant Material}

For DNA sequencing, sampling was largely similar to that of Gaudeul et al. (2016) and included both silica-dried material and herbarium specimens (app. A). The outgroup included 17 species from 13 genera of Orobanchaceae, among which five of the six species belonging to the four closely related genera recently segregated from Odontites (Bolliger 1996). Only Bornmuellerantha alshehbaziana Dönmez \& Mutlu was missing, but it was shown to be sister species to Bornmuellerantha aucheri (Boiss.) Rothm. (Scheunert et al. 2012). The ingroup included 25 out of the 27 species of Odontites (table 1; O. kaliformis and $O$. citrinus were missing), and most species were represented by several individuals, leading to a total of 184 samples (app. A). Samples named with the same number but different letters (e.g., Od40, Od40B, and Od40C) come from distinct plants but were either mounted on the same herbarium sheet (for Od18 and Od22) or belonged to the same population in the field. Because O. vernus and O. vulgaris were very difficult to distinguish morphologically (as previously noted by, e.g., Delgado et al. 2015), we refer to these samples as O. vernus/vulgaris.

For flow cytometry measurements, we used silica-dried leaves that have been shown to be suitable for such investigations (Suda and Travnicek 2006). In contrast, herbarium specimens cannot be exploited, because slow drying causes the degradation of cells' nuclei. All material was collected within a 3-yr pe- 

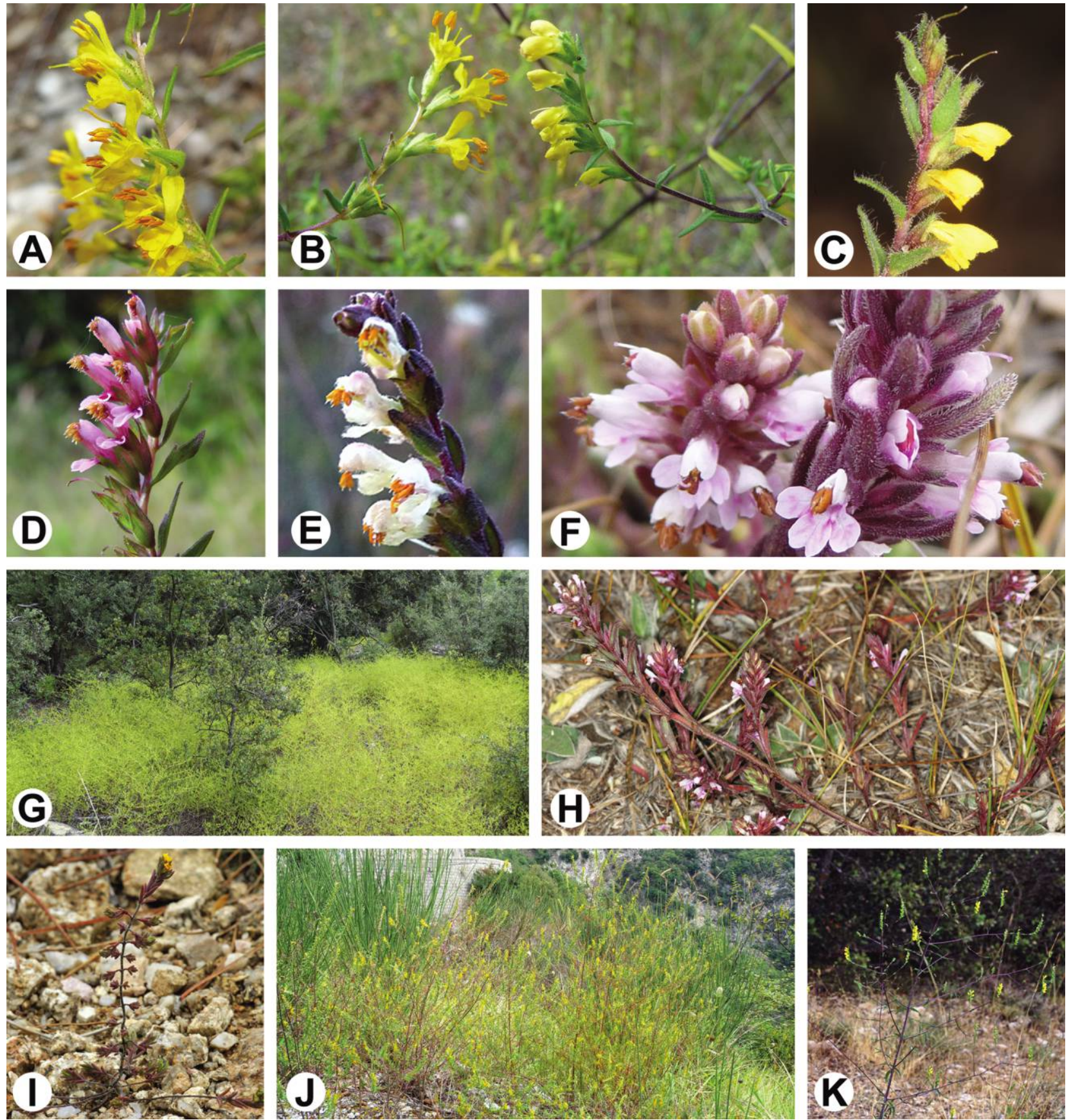

Fig. 1 Morphology and habit of some Odontites species. A, Odontites luteus (France). B, Odontites luteus (left) and O. viscosus (right; France). C, Odontites viscosus (Morocco). D, Odontites vernus/vulgaris (France). E, Odontites jaubertianus (France). F, Odontites maroccanus (Morocco). G, Odontites viscosus population (France). H, Odontites maroccanus (Morocco). I, Odontites corsicus (Corsica, France). J, Odontites luteus population (France). K, Odontites powellii (Morocco). Photos: M. Gaudeul, except $C, D, H, I, K$ by G. Rouhan.

riod (2007-2009) and preserved in the same optimal conditions of $-20^{\circ} \mathrm{C}$. Therefore, measurements can be compared without any bias among samples. All 21 species collected as silica-dried material were analyzed (i.e., all sequenced species except $O$. lapiei, O. purpureus, O. rigidifolius, and O. vulcanicus). Measure- ments were performed on 139 samples representing several populations per species whenever possible (table 2; app. B). For chromosome counts, seeds of O. lanceolatus, O. luteus, O. hispidulus, O. powellii, and O. vernus/vulgaris were collected in the field and preserved in paper envelopes at $4^{\circ} \mathrm{C}$. 


\section{Table 1}

Observed Monophyly of Odontites s.I. Species Based on nDNA ITS and ETS and the Combined cpDNA (psbA-trnH, trnL-trnF, and trnC-ycf6) Data Set

\begin{tabular}{|c|c|c|c|}
\hline $\begin{array}{l}\text { Morphological group } \\
\text { (or genus) and species }\end{array}$ & Monophyly based on ITS & Monophyly based on ETS & $\begin{array}{l}\text { Monophyly based on } \\
\text { combined cpDNA }\end{array}$ \\
\hline \multicolumn{4}{|l|}{ O. bocconii group: } \\
\hline bocconii & Uncertain & Yes & Uncertain (based on ML: yes) \\
\hline linkii & Uncertain & Uncertain & Uncertain \\
\hline corsicus & Yes & Yes & Yes \\
\hline bollianus & Yes & Yes & Yes \\
\hline jaubertianus & Uncertain & Uncertain & Uncertain \\
\hline kaliformis & Untested & Untested & Untested \\
\hline lapiei & Uncertain (1 sample only) & Uncertain (1 sample only) & Uncertain \\
\hline \multicolumn{4}{|l|}{ O. luteus group: } \\
\hline luteus & Uncertain & Uncertain & No \\
\hline hispidulus & Yes & Yes & Yes \\
\hline lanceolatus & Uncertain & Uncertain & No \\
\hline maroccanus & Yes & Yes & Yes \\
\hline powellii & Yes & Yes & Yes \\
\hline \multicolumn{4}{|l|}{ O. pyrenaeus group: } \\
\hline pyrenaeus & Yes & Yes (except based on ML: no) & Uncertain \\
\hline cebennensis & Yes & Yes & Uncertain \\
\hline \multicolumn{4}{|l|}{ O. purpureus group: } \\
\hline purpureus & Untested & Uncertain (1 sample only) & Uncertain (1 sample only) \\
\hline discolor & Uncertain & Uncertain & Yes \\
\hline squarrosus & Uncertain & Uncertain & Yes \\
\hline recordonii & Yes & Yes & Yes \\
\hline rigidifolius & Uncertain (1 sample only) & Uncertain (1 sample only) & Uncertain (1 sample only) \\
\hline \multicolumn{4}{|l|}{ O. triboutii group: } \\
\hline triboutii & Yes & Yes & Uncertain \\
\hline citrinus & Untested & Untested & Untested \\
\hline \multicolumn{4}{|l|}{ O. vernus group: } \\
\hline vernus/vulgaris & No & No & No \\
\hline litoralis & Uncertain & Uncertain & Uncertain \\
\hline violaceaus & Yes & Yes & Uncertain \\
\hline viscosus & Yes & Yes & Yes \\
\hline vulcanicus & Uncertain (1 sample only) & Uncertain (1 sample only) & Uncertain (1 sample only) \\
\hline \multicolumn{4}{|l|}{ Bartsiella: } \\
\hline rameauana & Uncertain ( 1 sample only) & Uncertain (1 sample only) & Uncertain (1 sample only) \\
\hline \multicolumn{4}{|l|}{ Bornmuellerantha: } \\
\hline aucheri & Yes & Yes & Yes \\
\hline alshehbaziana & Untested & Untested & Untested \\
\hline \multicolumn{4}{|l|}{ Macrosyringion: } \\
\hline glutinosum & Yes & Yes & Yes \\
\hline longiflorum & Yes & Yes & Yes \\
\hline
\end{tabular}

Note. Some species are clustered in morphological groups following Bolliger (1996). ML = maximum likelihood.

\section{DNA Sequencing}

Genomic DNA was extracted using the DNeasy Plant mini kit (Qiagen, Courtaboeuf, France). For herbarium specimens, we added $30 \mu \mathrm{L} \beta$-mercaptoethanol and $30 \mu \mathrm{L}$ proteinase $\mathrm{K}$ for the initial digestion step, which was carried out at $42^{\circ} \mathrm{C}$ over $12 \mathrm{~h}$ on a tipping plate. We sequenced the internal transcribed spacers (ITS) and the 5'-external transcribed spacer (ETS) from the nuclear ribosomal clusters. PCRs were carried in $25 \mu \mathrm{L}$ containing $1 \mu \mathrm{L}$ DNA template, $1 \mathrm{X}$ Taq buffer, $2.5 \mathrm{mM} \mathrm{MgCl}$, $0.2 \mathrm{mM}$ of each dNTP, $0.2 \mu \mathrm{M}$ of each primer, and $0.5 \mathrm{U}$ Taq polymerase (Taq CORE kit; MP Biomedicals, Illkirch, France). PCR primers were ITS4 (5'-TCCTCCGCTTATTGATATGC-3') and ITS5 (5'-GGAAGTAGAAGTCGTAACAAGG-3) for ITS (White et al. 1990) and 18S-IGS (5'-GAGACAAGCATATGAC TACTGGCAGGATCAACCAG-3'; Baldwin and Markos 1998) and ETS-B (5'-ATAGAGCGCGTGAGTGGTG-3'; Beardsley and Olmstead 2002) for ETS. After an initial denaturation of $5 \mathrm{~min}$ at $95^{\circ} \mathrm{C}$, the reaction profile was 40 cycles of $30 \mathrm{~s}$ denaturation at $95^{\circ} \mathrm{C}, 30 \mathrm{~s}$ annealing at $50^{\circ} \mathrm{C}$, and 1 min elongation at $72^{\circ} \mathrm{C}$, followed by a final elongation step of $10 \mathrm{~min}$ at $72^{\circ} \mathrm{C}$. PCR products were sequenced in both directions at the Centre National de Séquençage (Evry, France) using PCR primers and, for ETS, the additional primer 18S-E (5'-GCAGGATCAAC CAGGTAGCA-3'; Baldwin and Markos 1998). The same three cpDNA spacers ( $p s b \mathrm{~A}-t r n \mathrm{H}, \operatorname{trn} \mathrm{C}-y c f 6$, and $\operatorname{trn} \mathrm{L}-\operatorname{trn} \mathrm{F})$ used in 
Table 2

Genome Sizes (Estimated from Flow Cytometry Measurements) and Chromosome Numbers in Odontites Species

\begin{tabular}{|c|c|c|c|c|c|}
\hline \multirow[b]{2}{*}{ Species } & \multicolumn{3}{|c|}{ Nuclear genome size } & \multicolumn{2}{|l|}{ Chromosome no. } \\
\hline & No. samples & No. populations & Mean $\pm \mathrm{SD}(\mathrm{pg})$ & Previous reports (references) & This study \\
\hline O. bocconii & 4 & 2 & $1.39 \pm .04$ & $2 \mathrm{n}=24(2)$ & $\ldots$ \\
\hline O. cebennensis & 6 & 3 & $.99 \pm .04$ & $2 \mathrm{n}=24(3,5)$ & $\ldots$ \\
\hline O. citrinus & $\ldots$ & $\ldots$ & $\ldots$ & $\ldots$ & $\ldots$ \\
\hline O. corsicus & 4 & 1 & $1.14 \pm .04$ & $\ldots$ & $\ldots$ \\
\hline O. discolor & 4 & 1 & $1.42 \pm .07$ & $\ldots$ & $\ldots$ \\
\hline O. hispidulus ${ }^{\mathrm{a}}$ & 4 & 1 & $2.77 \pm .20$ & $2 n=20(3)$ & $2 n=4 x=40$ \\
\hline O. hollianus & 4 & 3 & $.87 \pm .03$ & $2 n=24(3)$ & $\ldots$ \\
\hline O. jaubertianus ${ }^{\mathrm{a}}$ & 8 & 4 & $2.16 \pm .15$ & $2 n=4 x=40$ & $\ldots$ \\
\hline O. kaliformis & $\ldots$ & $\ldots$ & $\ldots$ & $2 \mathrm{n}=22(5,6)$ & $\ldots$ \\
\hline O. lanceolatus & 6 & 4 & $1.12 \pm .04$ & $2 \mathrm{n}=20$ & $2 n=20$ \\
\hline O. lapiei & $\ldots$ & $\ldots$ & $\ldots$ & $\cdots$ & $\ldots$ \\
\hline O. linkii & 5 & 2 & $1.14 \pm .06$ & $\mathrm{n}=12$ & $\ldots$ \\
\hline O. litoralis & 7 & 3 & $1.30 \pm .14$ & $2 \mathrm{n}=18,20(1,3)$ & $\ldots$ \\
\hline O. luteus & 12 & 7 & $1.27 \pm .08$ & $2 \mathrm{n}=20(3,5)$ & $2 n=20$ \\
\hline O. maroccanus & 7 & 1 & $3.05 \pm .08$ & $\ldots$ & $\ldots$ \\
\hline O. powellii & 7 & 4 & $.55 \pm .02$ & $\ldots$ & $2 \mathrm{n}=20$ \\
\hline O. purpureus & $\ldots$ & $\ldots$ & $\ldots$ & $\ldots$ & $\ldots$ \\
\hline O. pyrenaeus & 4 & 2 & $1.09 \pm .04$ & $2 \mathrm{n}=24(3,5)$ & $\ldots$ \\
\hline O. recordonii & 5 & 2 & $1.23 \pm .05$ & $\begin{array}{l}2 \mathrm{n}=24(3) ; 2 \mathrm{n}=22,24,26,28(5) \\
\quad 2 \mathrm{n}=26(6)\end{array}$ & $\cdots$ \\
\hline O. rigidifolius & $\cdots$ & $\cdots$ & $\ldots$ & $2 \mathrm{n}=24(3)$ & $\ldots$ \\
\hline O. squarrosus & 4 & 1 & $1.12 \pm .08$ & $2 \mathrm{n}=24(3) ; 2 \mathrm{n}=22,24,26(4,5)$ & $\ldots$ \\
\hline O. triboutii & 13 & 4 & $1.63 \pm .13$ & $\ldots$ & $\ldots$ \\
\hline O. vernus/vulgaris (small genome) & 17 & 16 & $1.17 \pm .12$ & $2 \mathrm{n}=18,20(1,3,5,6)$ & $2 \mathrm{n}=18$ \\
\hline O. vernus/vulgaris (large genome) ${ }^{\mathrm{a}}$ & 5 & 5 & $2.30 \pm .15$ & $\begin{array}{l}2 \mathrm{n}=4 \mathrm{x}=40(1,3) ; 2 \mathrm{n}=4 \mathrm{x}=38,39 \\
\quad 40(5,6)\end{array}$ & $\ldots$ \\
\hline O. violaceus & 5 & 2 & $1.95 \pm .13$ & $\ldots$ & $\ldots$ \\
\hline O. viscosus & 8 & 6 & $2.25 \pm .10$ & $2 \mathrm{n}=24,26(3) ; 2 \mathrm{n}=20,22,24(5,6)$ & $\ldots$ \\
\hline O. vulcanicus & $\cdots$ & $\cdots$ & $\ldots$ & $\ldots$ & $\ldots$ \\
\hline
\end{tabular}

Note. Species are listed in alphabetical order. Unless otherwise stated, $2 \mathrm{n}=2 \mathrm{x}$. New counts obtained in this study are underlined. Literature references for chromosome numbers: 1: Snogerup (1977); 2: Ottonello et al. (1985); 3: Bolliger (1996); 4: Rico et al. (2008); 5: Rico (2009); 6: Delgado et al. (2015). For genome sizes estimated from flow cytometry measurements, see also fig. 4. For chromosome numbers in Odontites species, see also fig. 5 .

a Tetraploid species.

Gaudeul et al. (2016) were sequenced for 16 new samples, following the same protocol as earlier. Sequences were automatically aligned in MUSCLE v.3.6 (Edgar 2004) before the alignment was checked by eye and manually revised in BioEdit v.7.2.5 (Hall 1999).

\section{Molecular Phylogenetic Analyses}

The three data matrices (consisting of ITS, ETS, and the combined cpDNA regions, respectively) were analyzed using Bayesian inference (BI) and maximum likelihood (ML). Analyses were performed with coding gaps as present/absent in SeqState (Müller 2005) using the simple coding option (Simmons and Ochoterena 2000). We did not combine the nuclear ITS and ETS matrices because of supported disagreements between the corresponding topologies. The same conclusion resulted from an incongruence length difference (ILD) test (Farris et al. 1995), performed in PAUP* v.4.0b10 (Swofford 2002), which showed significant discrepancies $(P=0.01)$. This test was based on a reduced sampling - including one sample per species and with Bartsia alpina as the outgroup, leading to $n=34$ samples - and 100 replicates. On the contrary, the topologies based on the three cpDNA regions were in agreement among them.

Bayesian inferences were performed using MrBayes v.3.2.5 (Ronquist et al. 2011). For each region, the best-fitted model of nucleotide substitution was identified under the Akaike information criterion in MrModelTest v.2.3 (Nylander 2004; $\mathrm{SYM}+\mathrm{I}+\mathrm{G}$ for ITS; GTR + G for ETS, psbA-trnH, and $\operatorname{trn} \mathrm{C}-y c f 6$; GTR $+\mathrm{I}$ for $\operatorname{trn} \mathrm{L}-\operatorname{trn} \mathrm{F}$; and the binary model for coded indels). Two independent but parallel analyses were conducted using flat priors, starting from random trees and consisting of four chains each. The analyses were run for 5 million generations, sampling every 100 generations and with a $10 \%$ burn-in. Analysis of output parameters in Tracer v.1.6 (Rambaut et al. 2014) confirmed the convergence of chains and adequate burn-in length. Post-burn-in trees were pooled, and a $50 \%$ majority-rule consensus tree was computed with posterior probability (PP) estimates for all nodes.

The ML analyses were performed in raxmlGUI 1.5.1 (Silvestro and Michalak 2012; Stamatakis 2014) using the same par- 
titions and models of nucleotide evolution as for the BI. We performed 1000 rapid bootstrap (BS) replicates and searched for the best-scoring ML tree.

\section{Flow Cytometry Measurements}

Nuclear genome size was measured using flow cytometry at the Imagif Cell Biology platform (Gif-sur-Yvette, France) following the protocol described by Marie and Brown (1993) and Razafinarivo et al. (2012). Lycopersicon esculentum "Roma" $(2 \mathrm{C}=1.99 \mathrm{pg})$ and in a few cases Petunia hybrida PxPc6 $(2 \mathrm{C}=2.85 \mathrm{pg}$; Marie and Brown 1993) were used as internal standards. For each sample, about $1 \mathrm{~cm}^{2}$ of leaves from the target species and one of the internal standards were chopped together using a razor blade in a Petri dish with $800 \mu \mathrm{L}$ cold Galbraith nuclear-isolation buffer (Galbraith et al. 1983), brought to $0.5 \%(\mathrm{w} / \mathrm{v})$ Triton X-100, and supplemented with $5 \mathrm{mM}$ sodium metabisulfite, $1 \%$ polyvinylpyrrolidone 10,000 , and $50 \mu \mathrm{g} / \mathrm{mL}$ RNAse A (Roche Molecular, Mannheim, Germany). The suspension was filtered through a $48-\mu \mathrm{m}$ mesh nylon filter. The recovered nuclei were stained with $50 \mu \mathrm{g} / \mathrm{mL}$ propidium iodide (Sigma-Aldrich, Saint-Quentin, France) and incubated on ice for $5 \mathrm{~min}$, and their DNA content was determined using a CyFlow SL3 flow cytometer (Partec, Sainte-Geneviève-des-Bois, France) with a 532-nm laser. Total 2C DNA content was calculated on the basis of the linear relationship between fluorescent signals from stained nuclei of the unknown sample and the internal standard (DNA content $=$ [sample peak mode/standard peak mode] $\times 2 \mathrm{C}$ standard DNA content).

\section{Chromosome Counts}

Chromosome numbers were determined from actively growing root-tip meristems of germinating seedlings in Petri dishes or from plantlets obtained by in vitro culture. Root-tip meristems were collected and pretreated with a $0.002 \mathrm{M}$ solution of 8hydroxyquinoline for $2.5 \mathrm{~h}$ at $4^{\circ} \mathrm{C}$ and $2.5 \mathrm{~h}$ at room temperature or for $2.5-3 \mathrm{~h}$ at $16^{\circ} \mathrm{C}$. Pretreated samples were then fixed in $3: 1(\mathrm{v} / \mathrm{v})$ absolute ethanol/acetic acid mixture at room temperature for several hours and stored at $-20^{\circ} \mathrm{C}$ until use. For O. luteus and O. hispidulus, the preparations were made using enzymatic digestion of cell walls with an enzyme cocktail (Weiss-Schneeweiss et al. 2012). Preparations were made in a drop of $60 \%$ acetic acid, cover slips flipped off after freezing, and material stained with $2 \mathrm{ng} / \mathrm{mL}$ DAPI dissolved in the mounting antifade medium Vectashield (Vector Laboratories, Burlingame, CA). For the remaining species (O. lanceolatus, O. powellii, and O.vernus/vulgaris), root-tip meristems were hydrolyzed in $1 \mathrm{~N} \mathrm{HCl}$ for $8 \mathrm{~min}$ at $60^{\circ} \mathrm{C}$ and stained in acetic orceine. The squash was performed in a drop of $45 \%$ acetic acid or in acetic carmine. Preparations were examined with an epifluorescence microscope (Axio Imager M2; Zeiss, Vienna, Austria) using the AxioVision software (Zeiss) or with a Zeiss Axiophot microscope coupled to a CCD camera (Retiga 2000R; Princeton Instruments, Evry, France) and an image analyzer (Metavue v.7). At least five individuals per species were analyzed, and at least 10 complete and unambiguously countable chromosomal spreads were required for chromosome number to be established per individual.
Because we were faced with the technical challenges of germinating seeds and obtaining good-quality chromosome spreads in these species with small chromosomes (from 1 to 4-6.5 $\mu \mathrm{m}$; Snogerup 1977; Bolliger 1996), we tested whether a relation between nuclear genome size and chromosome number/ploidy levels could be observed among species and used as an alternative way to estimate ploidy. Such a relation was shown, e.g., in Sorbus (Rosaceae; Pellicer et al. 2012) or Knautia (Caprifoliaceae; Frajman et al. 2015 and references therein).

\section{Results}

\section{Phylogenetic Analyses}

Alignments included 801 positions for ITS (with 43 indels coded), 565 positions for ETS (with 61 indels), and 1970 positions for the combined cpDNA data set (with 172 indels and one 29-positions inversion coded; see Gaudeul et al. 2016). For each data set, only minor differences were identified among trees using BI and ML, and no conflict was supported. Because topologies using BI were the best-resolved and best-supported ones, we hereafter focus on these results (but BS values retrieved in the ML analyses were reported in figs. 2, 3).

ITS data set. The genus Odontites s.s. was not resolved as monophyletic given that three out of the four genera recently segregated from Odontites, Bartsiella, Bornmuellerantha, and Macrosyringion (but not Odontitella), were supported as belonging to a larger clade called Odontites s.l. ( $\mathrm{PP}=1$; fig. $2 A)$. Odontites s.l. was composed of two major clades (fig. $2 A$ ). The first one (clade A; PP $=0.88$ ) included three subclades: subclade A1 ( $\mathrm{PP}=1)$ included O. viscosus and Bartsiella (PP = 0.84) as well as O. squarrosus, O. bocconii, O. linkii, O. rigidifolius, and all seven North African taxa (later called the North African s.l. clade; PP $=1$ ). The second subclade (A2; $\mathrm{PP}=1$ ) comprised O. cebennensis and O. pyrenaeus. The third subclade (A3; PP $=0.98$ ) included Macrosyringion and Bornmuellerantha. The relationships among these three subclades were not supported $(\mathrm{PP}=0.51)$. The second major clade (clade $\mathrm{B} ; \mathrm{PP}=0.96$ ) was composed of two subclades: $\mathrm{B} 1$, comprising O. lanceolatus, O. luteus, O. corsicus, O. hollianus, O. recordonii, and four O. vernus/vulgaris individuals $(\mathrm{PP}=0.51$; but excluding O. recordonii and the four O. vernus/vulgaris individuals; $\mathrm{PP}=0.94)$, and $\mathrm{B} 2(\mathrm{PP}=1)$, including $\mathrm{O}$. jaubertianus, O. litoralis, O. vernus/vulgaris, and O. hispidulus. In 11 cases (out of 24 ; table 1 ), samples belonging to the same species formed highly supported exclusive lineages (all PP $=1$ except for O. corsicus $[\mathrm{PP}=0.85]$ and O. recordonii $[\mathrm{PP}=0.95]$; although the term "monophyletic" is somewhat inadequate at the species level [see Freudenstein 1998], we will use it hereafter for more convenience). In 12 other cases, species were unresolved due to samples from distinct species grouped in polytomies. Last, O. vernus/vulgaris was polyphyletic: most individuals belonged to subclade B2, while four samples $(\mathrm{Od} 50, \mathrm{Od} 50 \mathrm{~B}$, Od51, and Od51B) belonging to two populations were clustered with O. recordonii (subclade B1). DNA was extracted and sequenced twice independently, and all sequences were identical, confirming the corresponding phylogenetic placements.

ETS data set. Odontites s.l. (PP = 1) included Bartsiella and Bornmuellerantha, whereas Macrosyringion and Odontitella were retrieved with outgroups (fig. $2 B$ ). Odontites s.l. was 

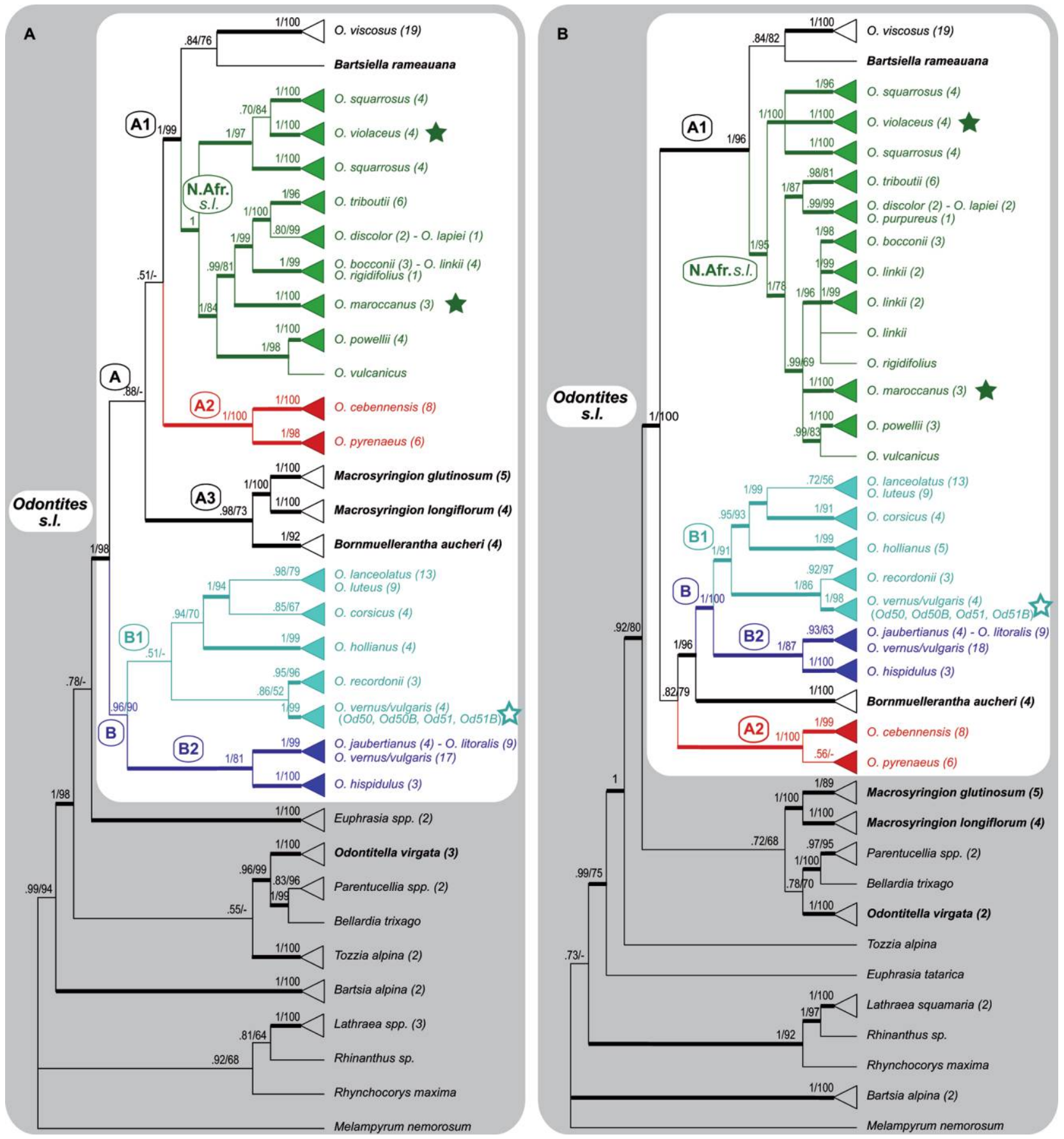

Fig. 2 Phylogenetic relationships among Odontites species and closely related genera based on the nDNA ITS data set $(A)$ and the nDNA ETS data set $(B)$. Trees are 50\% majority-rule consensus trees reconstructed by Bayesian inference in MrBayes. Posterior probabilities (PP)/ bootstraps are indicated at each node, and nodes with $\mathrm{PP}<0.50$ were collapsed. Thick lines correspond to nodes with PP $\geq 0.95$. Samples belonging to the same species were grouped when they formed a clade, and the number of samples is noted in brackets after the name of the species. Incongruences between nDNA (both ITS and ETS) and cpDNA, which are discussed in the main text, are indicated by filled stars when they involved all samples of a given species (O. maroccanus and O. violaceus) and by open stars when they involved only some samples of a species (in O. vernus/vulgaris). In the latter case, the name of these samples is indicated within brackets.

composed of two major clades. The first one $(\mathrm{PP}=1)$, including (O. viscosus, Bartsiella; $\mathrm{PP}=0.84$ ) and the North African s.l. subclade (PP $=1)$, was similar to subclade A1 of the ITS tree. The second major clade $(\mathrm{PP}=0.82)$ showed $(\mathrm{O}$. cebennensis,
O. pyrenaeus; subclade A2 of the ITS tree; PP $=1$ ) sister to all remaining taxa, with Bornmuellerantha sister to the clade $\mathrm{B}$ retrieved in the ITS tree (here with PP $=1$ ) and formed by the dichotomy between (O. lanceolatus, O. luteus, O. corsicus, 


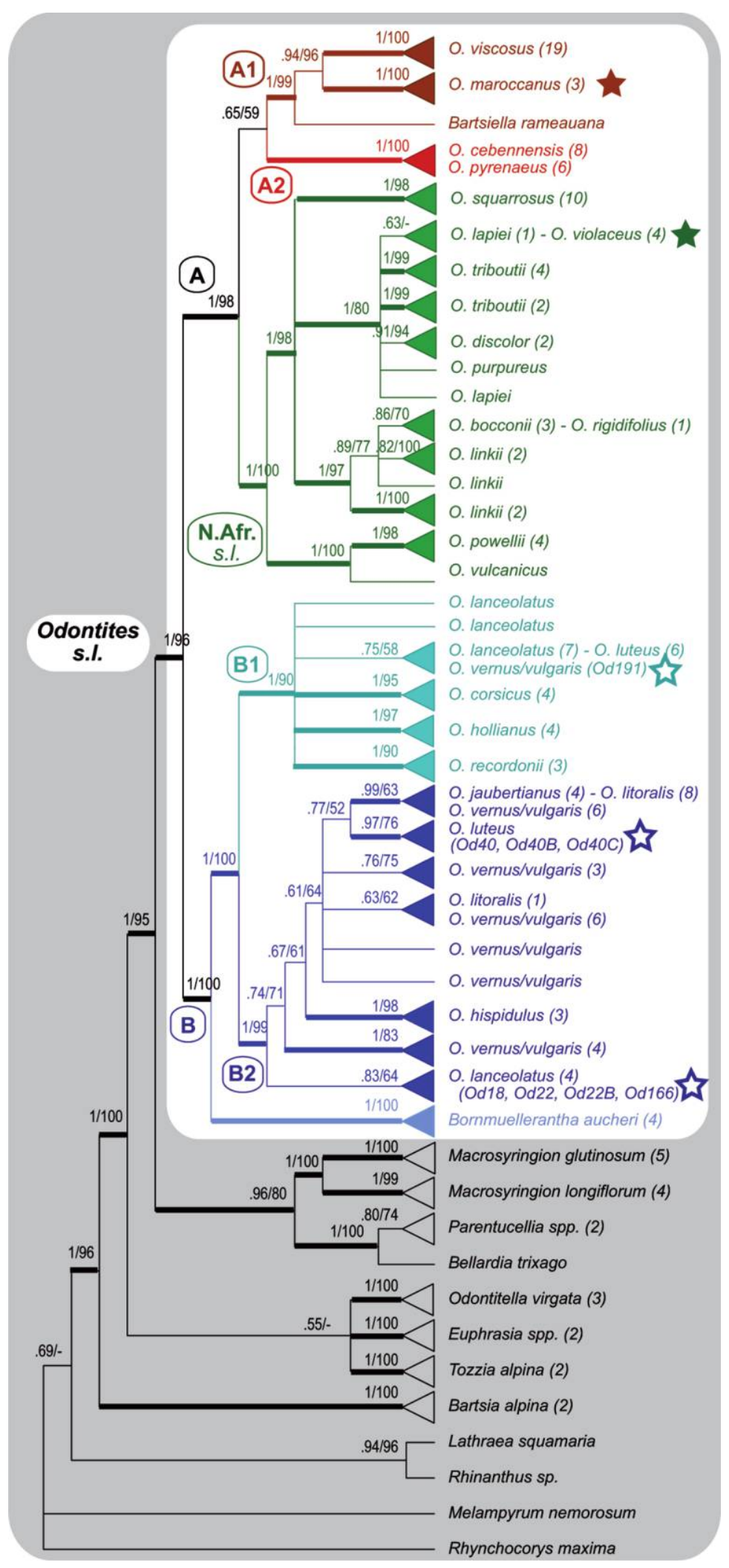

Fig. 3 Phylogenetic relationships among Odontites species and closely related genera based on the combined $p s b \mathrm{~A}-\operatorname{trn} \mathrm{H}, \operatorname{tr} n \mathrm{~L}-\operatorname{trn} \mathrm{F}$, and $\operatorname{trn} \mathrm{C}-y c f 6$ (cpDNA) data set. The $50 \%$ majority-rule consensus tree was reconstructed by Bayesian inference in MrBayes. Posterior probabilities (PP)/bootstraps are indicated at each node, and nodes with $\mathrm{PP}<50$ were collapsed. Thick lines correspond to nodes with PP $\geq 0.95$. Samples belonging to the same species were grouped when they formed a clade, and the number of samples is noted in brackets after the name of the species. Incongruences between nDNA (both ITS and ETS) and cpDNA, which are discussed in the main text, are indicated by filled stars when they involved all samples of a given species (O. maroccanus and O. violaceus) and by open stars when they involved only some samples of a species (in O. lanceolatus and O. luteus). In the latter case, the name of these samples is indicated within brackets. 
O. hollianus, O. recordonii, four samples of O. vernus/vulgaris; subclade B1; PP $=1)$ and $(O$. jaubertianus, O. litoralis, $O$. vernus/vulgaris, O. hispidulus; subclade $\mathrm{B} 2$; $\mathrm{PP}=1$ ).

This overall topology was mostly similar to the ITS topology, albeit with a few exceptions. The most striking one was the placement of Macrosyringion, either belonging to Odontites s.l. (based on ITS) or not (based on ETS). The position of Bornmuellerantha could also seem incongruent but does not involve any supported conflict: in the ITS tree, given the moderate posterior probability of clade A ( $\mathrm{PP}=0.88$, and this clade was not retrieved in the ML topology; fig. $2 A$ ), a sister relationship between Bornmuellerantha (and Macrosyringion) and clade B, as suggested by the ETS tree, cannot be ruled out. Similarly, the position of (O. cebennensis, O. pyrenaeus) differed between ITS and ETS, but the two topologies were not in conflict considering the moderate support for the placement of this clade sister to (clade B, Bornmuellerantha) in the ETS tree ( $\mathrm{PP}=0.82$ ). Within the North African s.l. clade, in contrast, species relationships differed among data sets: the group of (O. bocconii, O. linkii, O. rigidifolius) was most closely related to (O. triboutii, O. discolor, O. lapiei) based on ITS (PP $=1)$, whereas it was grouped with (O. powellii, O. vulcanicus) and O. maroccanus based on ETS (PP $=0.99$ ). Compared with ITS, the same species (plus O. bocconii) were each retrieved as strongly supported clades (table 1). Also congruent with the ITS tree, only O. vernus/vulgaris was polyphyletic, as four O. vernus/vulgaris samples were retrieved as sister group to O. recordonii $(\mathrm{PP}=1)$.

Combined chloroplast data set. Odontites s.l. $(\mathrm{PP}=1)$ included Bartsiella and Bornmuellerantha but neither Macrosyringion nor Odontitella. Odontites s.l. was composed of two major, highly supported clades (fig. 3). The first major clade $(\mathrm{PP}=1)$ was formed by the dichotomy $(\mathrm{PP}=0.65)$ between (O. viscosus, O. maroccanus, Bartsiella; $\mathrm{PP}=1$ ) sister to (O. cebennensis, O. pyrenaeus; subclade A2; $\mathrm{PP}=1$ ) on the one hand and the North African s.l. clade on the other (PP = 1). This first major clade comprised the same taxa as clade A defined with ITS, excluding (Macrosyringion, Bornmullerantha). The second major clade (PP $=1)$ was composed of Bornmuellerantha and taxa of clade $\mathrm{B}(\mathrm{PP}=1)$.

Comparison of nuclear and chloroplast topologies. In addition to the differences relative to the inclusion (based on ITS) or not (based on cpDNA and ETS) of Macrosyringion to Odontites s.l., several other incongruences were observed between the cpDNA and nuclear ITS and/or ETS topologies. First, $O$. maroccanus was retrieved with O. viscosus based on cpDNA, whereas it belonged to the North African s.l. clade based on ITS and ETS. Second, in contrast to the ITS and ETS trees, O. violaceus was more related to other North African taxa than to O. squarrosus based on cpDNA. Third, within the North African clade, O. powellii and O. vulcanicus were sister species to all others based on cpDNA, instead of O. squarrosus and $O$. violaceus in the ITS and ETS trees. Considering Bornmuellerantha, the cpDNA topology was identical to the ETS one, with this genus strongly supported as sister to clade $\mathrm{B}$ ( $\mathrm{PP}=$ 1). Also, the three data sets did not disagree about the position of (O. cebennensis, O. pyrenaeus) and allow hypothesizing the most likely topology: in the cpDNA tree, collapsing the poorly supported node grouping (O.cebennensis, O. pyrenaeus) with (O. viscosus, O. maroccanus, Bartsiella; $\mathrm{PP}=0.65)$ results in a highly supported trichotomy $(\mathrm{PP}=1)$ formed by these two clades and the North African s.l. clade. Given that both ITS and ETS showed strong support for the sister relationships between (O. viscosus, Bartsiella) and the North African s.l. clade $(\mathrm{PP}=1$ in both cases), this grouping is the most likely, and (O. cebennensis, O. pyrenaeus) is most probably sister to this group as shown in the ITS topology (fig. $2 A$ ).

Compared with ITS and ETS, mostly the same species were monophyletic or included in unresolved clades based on cpDNA (table 1). Odontites vernus/vulgaris, O. luteus, and O. lanceolatus were retrieved as polyphyletic: in subclade B1, we observed that Od191 (O. vernus/vulgaris; table 3 ) was grouped with $(O$. lanceolatus, O. luteus, O. corsicus, O. hollianus, O. recordonii) based on cpDNA, whereas it was with other O. vernus/vulgaris samples (in subclade B2) based on ITS and ETS. In subclade B2, Od40, Od40B, and Od40C (O. luteus; table 3) and Od18, Od22, Od22B, and Od166 (O. lanceolatus; table 3) segregated with (O. jaubertianus, O. litoralis, O. vernus/vulgaris, O. hispidulus) based on cpDNA, whereas they were grouped with other O. luteus and O. lanceolatus samples (in subclade B1) based on ITS and ETS. We observed that Od18B and Od18C, as well as Od166B, were retrieved with other O. lanceolatus samples as opposed to Od18 and Od166. Last, the O. vernus/vulgaris samples Od50, Od50B, Od51, and Od51B, which segregated with O. recordonii (in subclade $\mathrm{B} 1$ ) based on ITS and ETS, were grouped with other O. vernus/vulgaris samples (in subclade B2) based on cpDNA, as expected given their taxonomic identification (table 3).

\section{Flow Cytometry Measurements}

Four to 17 individuals of each of the 21 species analyzed were measured (mean \pm SD: $6.6 \pm 3.5$ ), originating from one to 16 distinct populations (mean \pm SD: $3.5 \pm 3.3$; table 2 ). To check the reproducibility of values, two separate measurements were performed on 11 samples and lead to SD spanning from $<0.01$ to 0.12 . Overall, nuclear DNA content ranged from $0.55 \pm$ $0.02 \mathrm{pg}$ in O. powellii to $3.05 \pm 0.08 \mathrm{pg}$ in O. maroccanus (table 2; fig. 4). All estimates were uniform within species, with only one exception: the values obtained for samples identified as O. vernus/vulgaris were bimodal. One group (called the small genome group) included 17 samples and had a mean DNA content of $1.17 \pm 0.11 \mathrm{pg}$, while the other group (called the large genome group) comprised five samples with a mean DNA content twice as high: $2 \mathrm{C}=2.32 \pm 0.14 \mathrm{pg}$.

\section{Chromosome Numbers}

We observed $2 \mathrm{n}=2 \mathrm{x}=20$ for O. lanceolatus and O. luteus and $2 \mathrm{n}=2 \mathrm{x}=18$ for O. vernus/vulgaris (small genome; fig. $5 \mathrm{~A}-$ 5C). We also established $2 \mathrm{n}=4 \mathrm{x}=40$ for O. hispidulus (fig. $5 D$ ) and $2 \mathrm{n}=2 \mathrm{x}=20$ for O. powellii (fig. $5 E$ ).

\section{Discussion}

\section{Molecular Data Shed Light on Systematics, Although Some Uncertainties Remain}

The absence of any clear morphological synapomorphy and previous molecular results made the monophyly of the genus Odontites questionable (Bolliger 1996; Scheunert et al. 2012; 


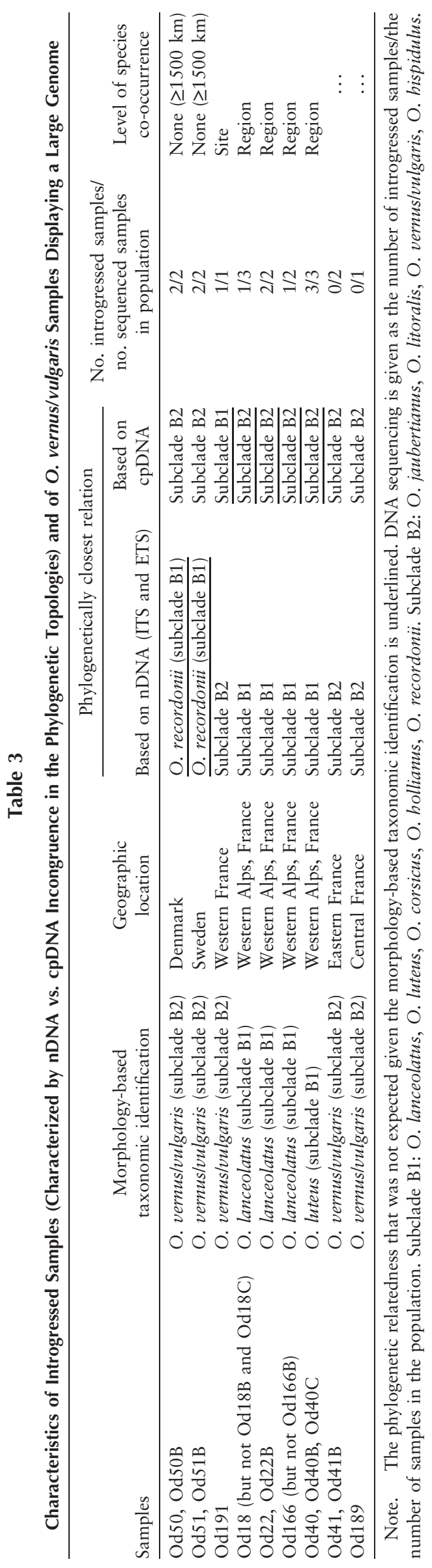

This content downloaded from 092.169.007.211 on January 11, 2018 18:07:56 PM 


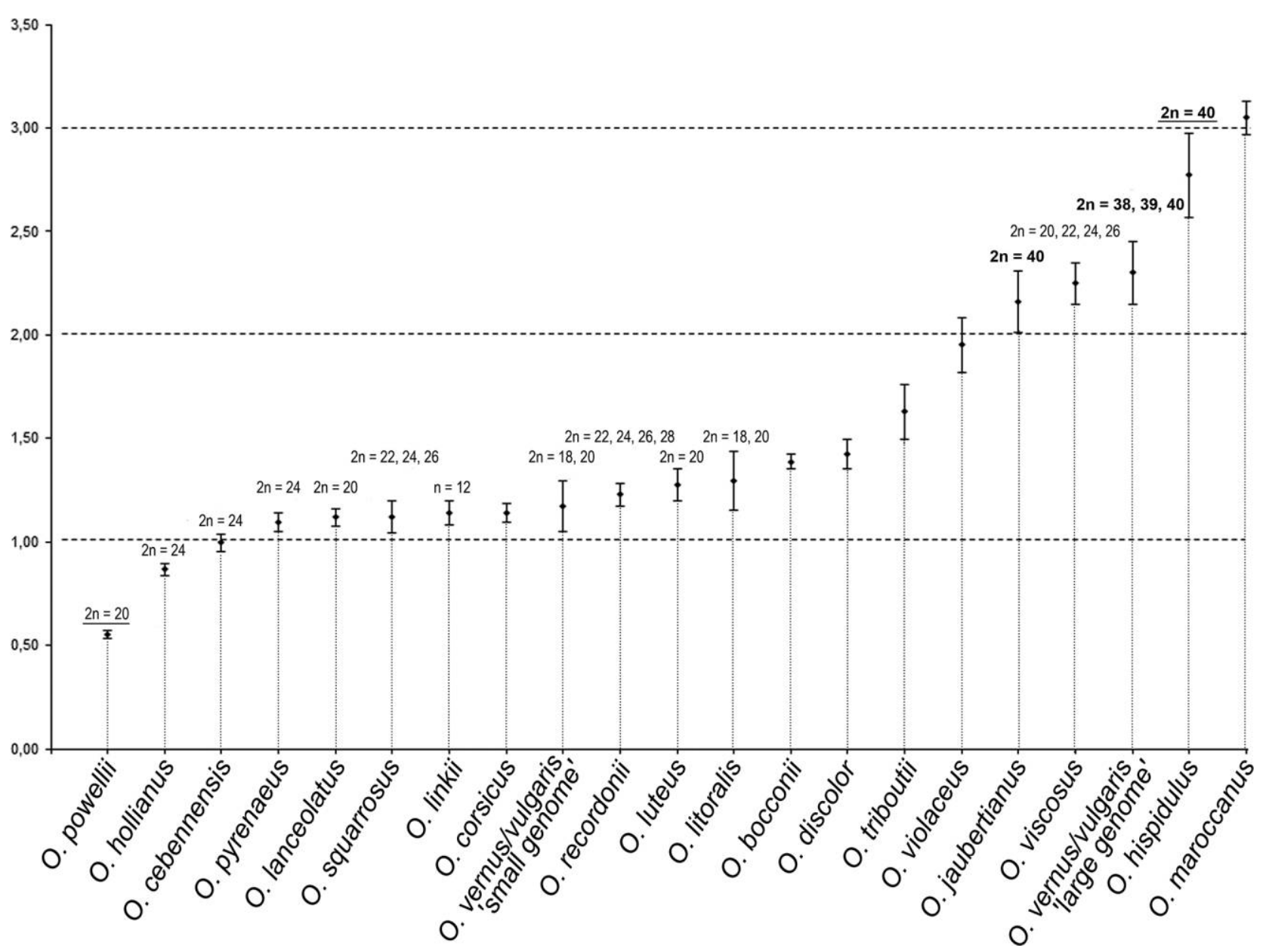

Fig. 4 Nuclear genome sizes (2C values in picograms) estimated from flow cytometry measurements in 21 Odontites species. Species are ordered from the smallest to the largest estimates. Tetraploid species appear in boldface, and new counts obtained in this study are underlined.

Gaudeul et al. 2016). In agreement with Scheunert et al. (2012) and Gaudeul et al. (2016), our data show that the two segregate genera Bartsiella and Bornmuellerantha should be returned to Odontites, while Odontitella is confirmed as a distinct lineage. The case of Macrosyringion is less clear-cut: Macrosyringion does not belong to Odontites based on cpDNA and ETS but is included into it based on ITS. Because ITS and ETS belong to a multigene family, there may be sequence variation between copies simply because they accumulate their own distinct mutations. Concerted evolution leads to the homogenization among copies, but ITS and ETS can experience different rates of homogenization resulting in incongruent phylogenetic patterns between them (Baldwin and Markos 1998; Alvarez and Wendel 2003). Recent hybridization can also cause the occurrence of divergent copies in the genome and possible ITS versus ETS incongruence (Mitsui et al. 2008; Soltis et al. 2008). Here, the reconstructed phylogenies could suggest the common ancestor of Parentucellia and Bellardia as the maternal ancestor of Macrosyringion (transmitting its chloroplast genome) and Bornmuellerantha as the paternal ancestor. This is congruent with the topologies recovered by Scheunert et al. (2012). However, Macrosyringion does not seem of recent origin (ca. 16.5 Ma;
Gaudeul et al. 2016), and additional investigations are therefore needed. For now, we recommend maintaining Macrosyringion as distinct from Odontites.

Low resolution was observed in several clades. It may be due to insufficient variability of the markers, especially since the involved species diversified recently $(<3.8 \mathrm{Ma}$; Gaudeul et al. 2016), but reticulate evolution is also known to possibly blur phylogenetic patterns (Linder and Rieseberg 2004). In support of such a hypothesis of reticulate evolution in Odontites, this study documented several cases of cpDNA versus nDNA incongruence (both ITS and ETS topologies being in agreement), suggesting (i) the ancient hybrid origin of some species and (ii) the occurrence of introgression between individuals of distinct species.

\section{Two Cases of Hybrid Speciation}

Two incongruences were found at the species level, in O. maroccanus and O. violaceus. Odontites maroccanus was retrieved within the North African s.l. clade based on nDNA but was sister species to O. viscosus based on cpDNA. This strongly suggests a hybrid origin for the species. We assume that parental 


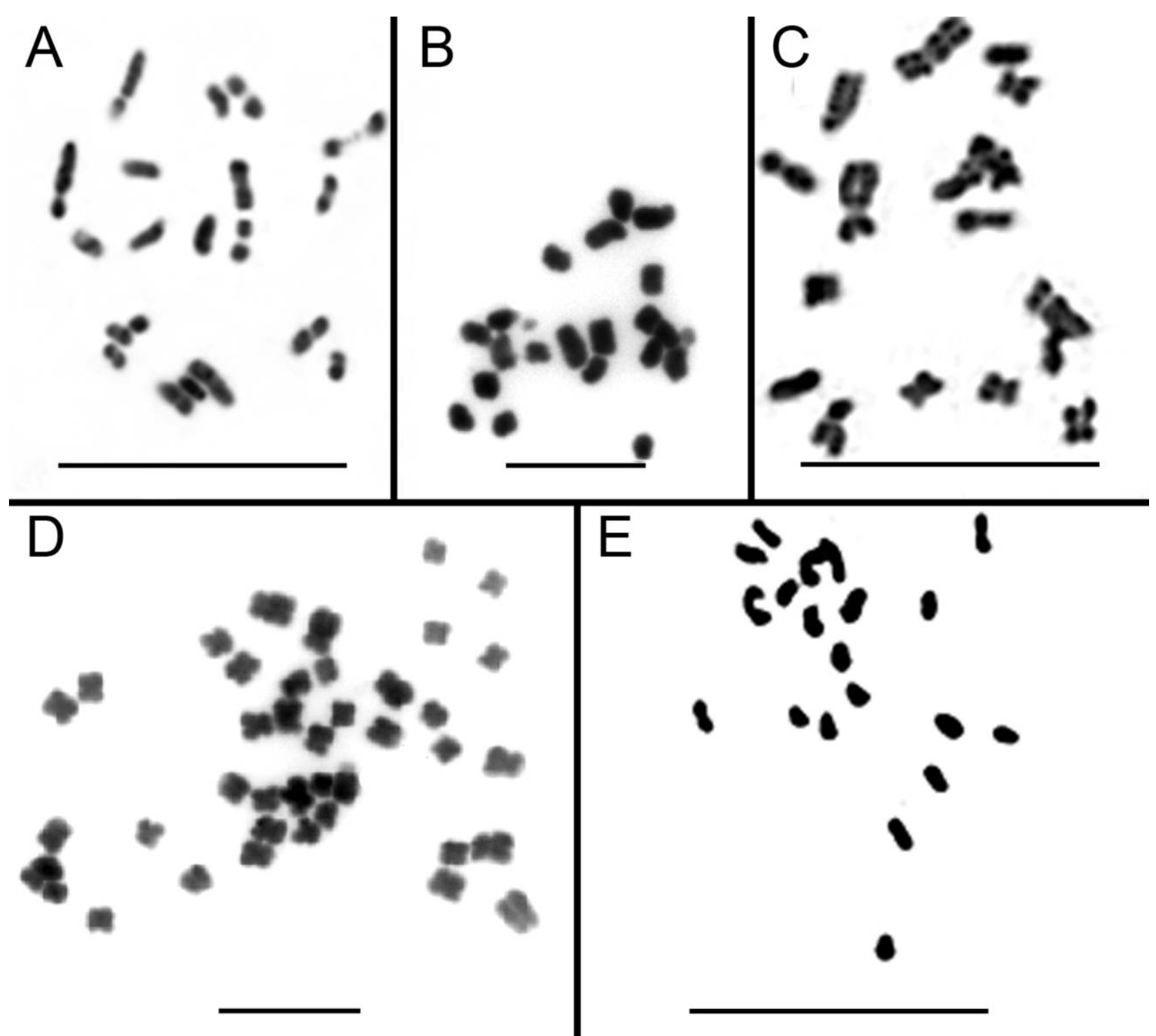

Fig. 5 Chromosome numbers of selected species of Odontites. A, Odontites luteus, Blanchemain s.n., France, $2 \mathrm{n}=2 \mathrm{x}=20.8$, Odontites lanceolatus, Gaudeul 74 (P00696025), France, $2 \mathrm{n}=2 \mathrm{x}=20$. C, Odontites vernus/vulgaris (small genome), Delahaye s.n. (P00684984), France, $2 \mathrm{n}=2 \mathrm{x}=18$. D, Odontites hispidulus, Tohmé s.n. (P02433310), Lebanon, $2 \mathrm{n}=4 \mathrm{x}=40$. E, Odontites powellii, Gaudeul 39 (P00577537), Morocco, $2 \mathrm{n}=2 \mathrm{x}=18$. Scale: $20 \mu \mathrm{m}$.

species most likely grow in the same area as their derivative hybrids, because the tight correlation between phylogenetic patterns and geography suggested limited dispersal (Gaudeul et al. 2016). Therefore, because O. powellii and O. vulcanicus are the only species of the North African s.l. clade found in the same region as O. maroccanus (the Middle Atlas mountains, Morocco), the latter may result from the introgression between the common ancestor of (O. powellii, O. vulcanicus) as the paternal parent and O. viscosus (which also occurs in the Middle Atlas, as subsp. eriopodus) as the maternal species. In O. maroccanus, hybridization was possibly accompanied by polyploidization; indeed, the species was characterized by the highest nuclear genome size observed in the genus to date $(2 \mathrm{C}=3.05 \mathrm{pg})$, with a larger estimate than the three known tetraploid O. hispidulus, O. jaubertianus, and O. vernus/vulgaris (large genome). However, the chromosome number is unknown in O. maroccanus, and the absence of a direct relation between nuclear DNA content and ploidy level precludes any conclusion (see below).

The hybrid origin of O. violaceus is also suggested, involving O. squarrosus as the paternal ancestor and one of the eastern North African species as the maternal ancestor (O. discolor, O. lapiei, O. purpureus, or O. triboutii). Based on the current data, we propose O. lapiei as the most likely maternal ancestor: like O. violaceus, it is the only other species to grow in the Djurdura region (Algeria) and, among the four possible ancestors, the only with a gross morphology comparable to O. vio- 
laceus (i.e., a small herbaceous plant). Odontites violaceus displays an intermediate nuclear genome size between the diploid and tetraploid species of the genus. However, as for O. maroccanus, it remains unknown whether polyploidization occurred.

\section{At the Individual Level: Evidence for Introgression}

Several instances of nDNA versus cpDNA incongruence were observed at the level of the individual (or group of individuals). Given that these incongruences were displayed by only a small subset of individuals, which belong to only a few species, we suggest that they are most likely explained by occasional introgression events after the species were formed (Howarth and Baum 2005). As we will illustrate in this section, the characteristics of these introgression events are very diverse: occurring between species that nowadays grow sympatrically or not, leading to the congruence between the morphology-based taxonomic identification and either nDNA or cpDNA, accompanied by genome doubling or not, and possibly involving only part of a population (table 3).

Out of the five O. vernus/vulgaris populations from Scandinavia studied, two populations are related to O. vernus/vulgaris samples based on cpDNA but related to O. recordonii based on nDNA (Od50, Od50B, Od51, and Od51B; table 3). Odontites recordonii is endemic to the southern border of the Pyrenees in Spain. At first sight, introgression therefore appears unlikely with the Scandinavian O. vernus/vulgaris, given the spatial distance $(\geq 1500 \mathrm{~km})$. Nevertheless, it may result from the potential coexistence of the two species during the glaciations of the Pleistocene, when northern Europe was entirely glaciated and many plant populations survived in more southerly latitudes. It could seem surprising that the nDNA sequences remained similar to O. recordonii in these Scandinavian populations, which would probably have colonized their current range long ago (at the end of the Last Glacial Maximum, ca. 10,000 yr ago; Hewitt 2004), since O. recordonii does not occur in Scandinavia; indeed, crossings with other typical O. vernus/vulgaris plants in Scandinavia should have led to the gradual decrease in frequency of nDNA sequences typical of O. recordonii. We propose that the introgressed Scandinavian plants of O. vernus/ vulgaris are reproductively isolated and that there is no gene flow between the introgressed samples and other nearby, nonintrogressed Scandinavian O. vernus/vulgaris populations. We observed twice as high nuclear DNA contents in the introgressed samples (table 3), suggesting that introgression may have triggered polyploidization and that these populations are composed of allotetraploid individuals. Reproductive isolation among populations could therefore be explained by the difference in genome size and by chromosomal rearrangements that often take place following such genome doubling (Weiss-Schneeweiss et al. 2013). An alternative hypothesis is that there has been extinction of a species closely related to O. recordonii, which may have had a wider or more northern distribution and underwent introgression with some Scandinavian populations of O. vernus/ vulgaris.

Conversely, three samples from two populations from eastern and central France, also characterized by a large genome, do not show any incongruence between phylogenetic relationships inferred from cpDNA and nDNA (Od41, Od41B, and Od189; table 3). They could be either diploids that have ex- perienced genome expansion or (most likely) autotetraploids, as previously suspected for O. vernus (Bolliger 1996). Again in O. vernus/vulgaris, another case of introgression is observed in the opposite direction: whereas the example of Scandinavian populations shows agreement between morphological identification and cpDNA relatedness, an O. vernus/vulgaris sample from western France (Od191; table 3) is related to O. vernus/ vulgaris based on ITS and ETS but related to (O. luteus, O. lanceolatus, O. corsicus, O. hollianus, O. recordonii) based on cpDNA. We observed genome doubling in this case, and introgression appears likely since the two species $O$. vernus/vulgaris and $O$. luteus are growing within the same site.

Other instances of cpDNA versus nDNA incongruence were provided by a few O. lanceolatus and O. luteus samples from four populations of the Western Alps: they were grouped with conspecific individuals based on nDNA but related to $(O$. jaubertianus, O. litoralis, O. vernus/vulgaris) based on cpDNA (table 3). We interpreted these patterns as the signature of introgression events between O. lanceolatus or O. luteus (respectively) as the paternal species and most probably O. vernus/vulgaris as the maternal parent, since only O. vernus/vulgaris (but neither O. jaubertianus nor O. litoralis) also occurs in the Western Alps. Such events did not trigger genome doubling. Interestingly, in two populations out of four, only part of the population displays the signature of introgression as shown by $\mathrm{Od} 18$ versus Od18B and Od18C and Od166 versus Od166B, respectively, which grow in the same population but exhibit clearly divergent cpDNA sequences (table 3). It remains unknown whether this coexistence is stable in time or whether one group of individuals (either the typical or the introgressed ones) will increase in number and ultimately invade the population.

\section{No Direct Relation between Nuclear Genome Size and Chromosome Number or Ploidy Level among Species}

Odontites show a wide range of variation in both nuclear genome size (spanning a ca. sixfold range, from $2 \mathrm{C}=0.55 \mathrm{pg}$ to $2 \mathrm{C}=3.05 \mathrm{pg}$ ) and chromosome numbers. Taking into account the literature data, chromosome numbers and ploidy levels range from $2 \mathrm{n}=2 \mathrm{x}=18$ in the diploid $O$. litoralis and $O$. vernus/vulgaris (small genome) to $2 \mathrm{n}=4 \mathrm{x}=40$ in the tetraploid O. hispidulus, O.jaubertianus, and O. vernus/vulgaris (large genome; table 2). Our flow cytometry results mostly agree with published genome sizes: Koutecky et al. (2012) estimated mean $2 \mathrm{C}$ values of 1.20 and $2.35 \mathrm{pg}$ for the small genome and large genome of $O$. vernus/vulgaris, respectively, compared to our estimates of 1.17 and 2.30 pg. As reported by Koutecky et al. (2012) and Delgado et al. (2015) based on chromosome counts, these two groups of individuals might represent two ploidy levels (diploids and tetraploids) within the O. vernus/O. vulgaris species complex. Moreover, identical chromosome numbers of $2 \mathrm{n}=2 \mathrm{x}=20,2 \mathrm{n}=2 \mathrm{x}=20$, and $2 \mathrm{n}=2 \mathrm{x}=18,20$ were previously reported for O. lanceolatus, O. luteus, and O. vernus/ vulgaris (small genome), respectively (Snogerup 1977; Bolliger 1996; Rico 2009; Delgado et al. 2015). For O. hispidulus, our chromosome count of $2 \mathrm{n}=4 \mathrm{x}=40$ differs from the published value of $2 n=2 x=20$ (Bolliger 1996). However, this latter value was not based on experimental data but extrapolated from those obtained for O. luteus and O. lanceolatus, because O. hispidulus was hypothesized to belong to the same group of species 
based on morpho-anatomical characters (Bolliger 1996). Therefore, we provide the first original chromosome counts for both O. hispidulus $(2 \mathrm{n}=4 \mathrm{x}=40)$ and O. powellii $(2 \mathrm{n}=2 \mathrm{x}=20)$.

Interspecific variation in nuclear genome size is usually due to either polyploidization, which results in the instant multiplication of whole chromosome sets, or the gradual accumulation/ deletion of (most often) repetitive DNAs (e.g., retrotransposons or tandem repeats; Weiss-Schneeweiss and Schneeweiss 2013). Interspecific variation in chromosome number, on the other hand, may result from polyploidization or dysploidy, which entails karyotype rearrangements (with no or little change in DNA content; Weiss-Schneeweiss and Schneeweiss 2013). In Odontites, species displaying the largest nuclear genome sizes include the tetraploids O. hispidulus $(2 \mathrm{C}=2.77 \mathrm{pg})$, O. jaubertianus $(2 \mathrm{C}=2.16 \mathrm{pg}$ ), and O. vernus/vulgaris (large genome; $2 \mathrm{C}=$ $2.30 \mathrm{pg}$ ). However, O. viscosus displays a genome size of as much as $2 \mathrm{C}=2.25 \mathrm{pg}$ and was reported to be diploid with $2 \mathrm{n}=20,22,24,26$, a chromosome number similar to several other diploid species with clearly smaller genome sizes (e.g., O. cebennensis and $\mathrm{O}$. pyrenaeus both have $2 \mathrm{n}=24$ and $2 \mathrm{C}=$ 0.99 and $1.09 \mathrm{pg}$, respectively; table 2). Although nuclear genome size and chromosome number were not estimated on the same individuals, both were investigated on several individuals independently and found to be uniform within the species. Odontites viscosus may have a polyploid history followed by complete genome diploidization (Weiss-Schneeweiss and Schneeweiss 2013) or have experienced genome expansion through the accumulation of repetitive DNA. As opposed to O. viscosus, the diploid $\mathrm{O}$. powellii displays a much smaller genome size $(2 \mathrm{C}=0.55 \mathrm{pg})$ compared to other diploid species. Therefore, flow cytometry measurements cannot be used to extrapolate ploidy levels among species of Odontites. Pellicer et al. (2013) showed that polyploidy could explain the diversity of genome size in one group of Nymphaea, while the amplification of repetitive DNA sequences was the main contributor to this diversity in another, even closely related groups (Nymphaea subgenera Anecphya and Brachyceras, respectively; Nymphaeaceae). Other examples with no relation between genome size, chromosome number, and ploidy level were provided by, e.g., Talent and Dickinson (2005) in Crataegus and Mespilus (Rosaceae), WeissSchneeweiss et al. (2006) in Orobanche (Orobanchaceae), Niketic et al. (2013) in Cerastium (Caryophyllaceae), Escudero et al. (2015) in Carex (Cyperaceae), and Rockinger et al. (2016) in Carica (Caricaceae).

It remains to be determined what the ploidy level of $\mathrm{O}$. $m a$ roccanus is (the species is characterized by the largest nuclear genome size), whether it is polyploid or whether its genome increased in size due to amplification of repetitive DNAs on dip- loid level. Chromosome numbers and ploidy levels of O. triboutii and $O$. violaceus also need to be investigated. Their nuclear genome size being intermediate between most diploid and tetraploid species, they may be either diploid, triploid, or tetraploid. Such data would bring valuable information about the mechanisms involved in the evolution of genome size in Odontites.

\section{Conclusions and Perspectives}

This study allowed clarifying the systematics of the Mediterranean genus Odontites. In particular, it showed that the genera Bartsiella and Bornmuellerantha should be merged into Odontites. In addition, phylogenetic approaches based on different genomic regions allowed suggesting several cases of introgression and hybrid speciation that gave rise to O. maroccanus and O. violaceus. The analysis of additional nuclear DNA markers, such as low-copy nuclear genes, is needed to verify these results and provide more information on the potential parental species involved. The introgression/hybridization events displayed a wide range of characteristics (e.g., in terms of number of individuals involved, direction of introgression, and incidence or not of genome doubling), and extensive reticulate evolution is also expected to occur within several not fully resolved clades. In these groups where diversification is probably recent and still ongoing, the phylogenetic species concept does not appear to be the best suited, and one should probably rather adopt a multilocus "genotypic cluster" species concept: based on this concept, a species is seen as a group of individuals sharing a common gene pool that persists in nature over time and in the face of possible gene flow from other groups (therefore alleviating the need for species to consist of phylogenetically exclusive lineages; de Queiroz 2007; Mallet 2007; Nolte and Tautz 2010). In such a context, population-level investigations using multiple and highly variable plastid and nuclear markers would be desirable to further study the evolutionary dynamics of populations and species. This survey should be complemented by chromosome counts, since nuclear genome sizes alone cannot translate into ploidy levels. Such genetic data, interpreted together with information on the biological, geographical, and ecological attributes of species, will allow investigating the buildup of species diversity in Odontites. This genus appears as an interesting group to study species diversification, providing (i) closely related species that display various (e.g., morphological, ecological, or phenological) characters, (ii) cases of study at different temporal stages in the process of differentiation, and (iii) several contact zones between species, allowing investigations on reproductive isolation and where hybrid gene pools may evolve as a first step toward hybrid speciation (Nolte and Tautz 2010).

\section{Appendix A}

\section{Voucher Information and GenBank Accession Numbers for Sequences Used in This Study}

In psbA-trn H, a 105-bp insertion was found in the three outgroups Melampyrum nemorosum, Rhynchochorys maxima, and Rhinanthus sp. and was removed from the analyses to avoid introducing massive missing data in the ingroup. Also, a 29-bp inversion was identified in some previously sequenced individuals. These fragments were reverse complemented, and a binary character was coded to record the original orientation. In $\operatorname{trn} \mathrm{C}-y c f 6$, we removed a 26-pb insertion observed only in Rhinanthus sp. and four insertions ( $\leq 10 \mathrm{bp}$ ) observed only in Melampyrum nemorosum. Species, DNA code, source of material (herbarium/

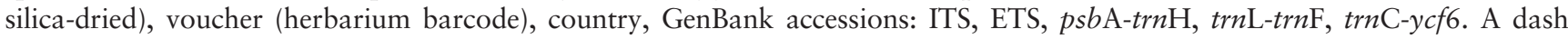


indicates that the sequence or information is unavailable, and an asterisk indicates a newly obtained sequence. Herbarium acronyms follow Thiers (2017).

Odontites bocconii, Od78, h, Akeroyd 3664 (E00094634), Italy: Sicily, MF444517*, MF444330*, KU216822, KU234954, —; Od86, s, Certa s.n. (PAL90580), Italy: Sicily, MF444518*, MF444331*, KU216823, KU234955, KU235070; Od87, s, Domina s.n. (PAL90581), Italy: Sicily, MF444519*, MF444332*, KU216824, KU234956, KU235071; O. cebennensis, Od23, h, Bolliger O-43 (P00699814), Spain, MF444476*, MF444363*, KU216761, KU234836, KU235060; Od24, h, Bolliger O-44 (P00699812), Spain, MF444477*, MF444364*, KU216762, KU234837, KU235053; Od25, h, Bolliger O-45 (P00699813), Spain, MF444478*, MF444365*, KU216763, KU234838, KU235055; Od26, h, Bolliger O-23 (P00699810), Spain, MF444479*, MF444366*, KU216764, KU234839, KU235061; Od164, s, Gaudeul 14 (P00695946), Spain, MF444480*, MF444367*, KU216853, KU234875, KU235032; Od165, s, Gaudeul 15 (P00695947), Spain, MF444481*, MF444368*, KU216852, KU234874, KU235031; Od168, s, Leblond s.n. (P00685030), France, MF444482*, MF444369*, KU216851, KU234873, KU235030; Od169, s, Leblond s.n. (P00685030), France, MF444483*, MF444370*, KU216850, KU234872, KU235029; O. corsicus, Od11, h, Chevalier s.n. (P), France: Corsica, MF444574*, MF444403*, KU216896, KU234861, KU235036; Od130, h, Jeanmonod 5512 (G00081418), France: Corsica, MF444575*, MF444404*, KU216895, KU234860, KU235037; Od133, h, Lambinon 90/Co/476 (G00081417), France: Corsica, MF444576*, MF444405*, KU216894, KU234859, 一; Od170, s, Rouhan 1108 (P00695915), France: Corsica, MF444577*, MF444407*, KU216849, KU234871, KU235028; O. discolor, Od141, s, Vela s.n. (P00685037), Algeria, MF444510*, MF444348*, KU216772, KU234941, KU235083; Od142, s, Vela s.n. (P00685037), Algeria, MF444511*, MF444349*, KU216773, KU234942, KU235082; O. hispidulus, Od67, s, Bou Dagher-Kharrat s.n. (P02433311), Lebanon, MF444608*, MF444439*, KU216857, KU234908, KU235017; Od68, s, Bou Dagher-Kharrat s.n. (P02433311), Lebanon, MF444609*, MF444440*, KU216858, KU234909, KU235018; Od69, s, Bou Dagher-Kharrat s.n. (P02433311), Lebanon, MF444610*, MF444441*, KU216859, KU234910, KU235019; O. hollianus, Od44, h, Metlesics s.n. (WU), Portugal: Madeira, MF444578*, MF444408*, KU216846, KU234868, KU235024; Od160, s, Gaudeul 105 (P00696073), Portugal: Madeira, MF444579*, MF444406*, -, KU234878, KU235025; Od161, s, Gaudeul 105 (P00696073), Portugal: Madeira, —, MF444409*, _, - _- Od162, s, Gaudeul 106 (P00696076), Portugal: Madeira, MF444580*, MF444410*, KU216855, KU234877, KU235034; Od163, s, Gaudeul 107 (P00696077), Portugal: Madeira, MF444581*, MF444411*, KU216854, KU234876, KU235033; O. jaubertianus, Od48, s, Gaudeul 2 (P00695918), France, MF444604*, MF444435*, KU216868, KU234897, KU235004; Od49, s, Gaudeul 4 (P00695924), France, MF444605*, MF444436*, KU216869, KU234896, KU235005; Od171, s, Gaudeul 118 (P00696092), France, MF444606*, MF444437*, KU216848, KU234870, KU235027; Od172, s, Gaudeul 110 (P00696081), France, MF444607*, MF444438*, KU216847, KU234869, KU235026; O. lanceolatus, Od17, s, Douzet s.n. (-), France, MF444571*, MF444390*, KU216883, KU234862, KU235038; Od18, h, Bolliger O-54 (P00700018), France, MF444563*, MF444391*, KU216866, KU234904, KU235020; Od18B, h, Bolliger O-54 (P00700019), France, MF444564*, MF444392*, KU216904, KU234968, KU235097; Od18C, h, Bolliger O-54 (P00700020), France, MF444565*, MF444393*, KU216905, KU234969, KU235098; Od19, h, Bolliger O-55 (P00700021), France, MF444566*, MF444394*, KU216884, KU234863, KU235035; Od20, h, Bolliger O-67 (P00700026), France, MF444567*, MF444395*, KU216885, KU234864, KU234990; Od21, h, Bolliger O-13 (P00700016), France, MF444568*, MF444396*, KU216886, KU234865, KU235042; Od22, h, Bolliger O-69 (P00700027), France, MF444569*, MF444397*, KU216881, KU234905, KU235021; Od22B, h, Bolliger O-69 (P00700027), France, MF444570*, MF444398*, KU216906, KU234970, KU235099; Od43, h, Bolliger O-72 (P00699895), Italy, MF444572*, MF444399*, MF444664*, MF444650*, MF444635*; Od166, s, Gaudeul 70 (P00696007), Italy, MF444611*, MF444401*, MF444665*, —, MF444636*; Od166B, s, Gaudeul 70 (P00696007), Italy, MF444573*, MF444400*, MF444666*, MF444651*, MF444637*; Od167, s, Gaudeul 73 (P00696022), France, MF444612*, MF444402*, MF444667*, -, MF444638*; O. lapiei, Od139, h, Beloued s.n. (INA Alger, Algeria), Algeria, —, MF444346*, KU216833, KU234966, —; Od176, h, Dubuis 18423 (P04047717), Algeria, MF444540*, MF444347*, 一, KU234974, KU235103; O. linkii, Od6, h, de Heldreich 1571 (P06137728), Greece, —, MF444324*, KU216815, KU234961, —; Od7, h, Greuter 16856 (P04065969), Greece, MF444512*, MF444325*, KU216816, KU234963, KU235088; Od14, s, Gücel s.n. (-), Cyprus, MF444514*, MF444327*, KU216825, KU234933, KU235086; Od15, s, Gücel s.n. (-), Cyprus, MF444515*, MF444328*, KU216826, KU234934, KU235085; Od60, s, Gardner 8085 (P00684960), Greece, MF444513*, MF444326*, KU216821, KU234962, KU235087; O. litoralis, Od5, s, Christenhusz 4495 (P00598561), Finland, MF444602*, MF444426*, KU216882, KU234899, KU235015; Od57, s, Pankhurst 07/43 (E00314995), Scotland, Outer Hebrides, MF444595*, MF444434*, KU216873, KU234893, KU235012; Od58, s, Pankhurst 07/46 (E00314994), Scotland, Outer Hebrides, MF444596*, MF444429*, KU216874, KU234892, KU235013; Od59, s, Pankhurst 07/48 (E00314997), Scotland, Outer Hebrides, MF444597*, MF444430*, KU216875, KU234891, KU235000; Od81, h, Laine s.n. (E00247556), Finland, MF444598*, MF444431*, KU216877, KU234890, KU235014; Od82, h, Laine s.n. (E00247557), Finland, MF444603*, MF444427*, KU216878, KU234889, KU235016; Od156, h, Snogerup 158 (UPS-V203580), Sweden, MF444599*, MF444433*, KU216864, KU234903, KU235001; Od157, h, Hjertson 20 (UPS-V138149), Sweden, MF444600*, MF444432*, KU216863, KU234886, KU234995; Od158, h, Snogerup 73 (UPS-V203935), Finland, MF444601*, MF444428*, KU216856, KU234900, KU235002; O. luteus, Od37, s, Douzet s.n. (-), France, MF444554*, MF444381*, KU216893, KU234867, KU235041; Od40, s, Rouhan 733 (P00684966), France, MF444555*, MF444382*, KU216887, KU234906, KU235003; Od40B, s, Rouhan 733 (P00684966), France, MF444556*, MF444383*, KU216907, KU234971, KU235100; Od40C, s, Rouhan 733 (P00684966), France, MF444557*, MF444384*, KU216908, KU234972, KU235101; Od45, s, Vela s.n. (P00684964), France, MF444558*, MF444385*, KU216888, KU234879, KU235039; Od46, s, Gaudeul 13 (P00695944), Spain, 
MF444559*, MF444386*, KU216889, KU234880, KU235043; Od47, s, Gaudeul 18 (P00695952), Spain, MF444560*, MF444387*, KU216890, KU234881, KU235044; Od55, s, Vela s.n. (-), France, MF444561*, MF444388*, KU216891, KU234882, KU235045; Od92, s, Tribsch 4651 (P00684961), Austria, MF444562*, MF444389*, KU216892, KU234885, KU235040; O. maroccanus, Od79, h, Jahandiez 881 (E00247554), Morocco, MF444520*, MF444337*, KU216788, KU234856, KU235049; Od102, h, Gattefossé s.n. (B100271795), Morocco, MF444521*, MF444338*, KU216789, KU234857, KU235050; Od124, s, Gaudeul 40 (P00577538), Morocco, MF444522*, MF444339*, KU216790, KU234858, KU235051; O. powellii, Od0, h, Bolliger O-163 (P06137733), Morocco, MF444523*, 一, KU216812, KU234847, KU235069; Od121, s, Gaudeul 66 (P00696004), Morocco, MF444524*, MF444333*, KU216844, KU234850, KU235066; Od125, s, Gaudeul 39 (P00577550), Morocco, MF444525*, MF444334*, KU216813, KU234848, KU235067; Od126, s, Gaudeul 50 (P00577543), Morocco, MF444526*, MF444335*, KU216814, KU234849, KU235068; O. purpureus, Od131, h, Letourneux s.n. (MPU009964), Algeria, -, MF444350*, KU216832, KU234935, -; O. pyrenaeus, Od27, h, Montserrat 4078 (P02432234), Spain, MF444470*, MF444371*, KU216765, KU234840, KU235054; Od28, h, Bolliger O-36 (P00700031), Spain, MF444471*, MF444372*, KU216766, KU234841, KU235056; Od29, h, Bolliger O-38 (P00700033), Spain, MF444472*, MF444373*, KU216767, KU234842, KU235057; Od31, h, Bolliger O-31 (P00700029), Spain, MF444473*, MF444374*, KU216768, KU234845, KU235052; Od65, s, Gaudeul 27 (P00695971), Spain, MF444474*, MF444375*, KU216769, KU234843, KU235058; Od66, s, Gaudeul 27 (P00695971), Spain, MF444475*, MF444376*, KU216770, KU234844, KU235059; O. recordonii, Od32, h, Bolliger O-30 (P00699887), Spain, MF444584*, MF444414*, KU216897, KU234866, KU235046; Od63, s, Gaudeul 20 (P00695956), Spain, MF444585*, MF444415*, KU216898, KU234883, KU235047; Od64, s, Gaudeul 22 (P00695959), Spain, MF444586*, MF444416*, KU216899, KU234884, KU235048; O. rigidifolius, Od93, h, Wentz s.n. (GOET), Italy: Sicily, MF444516*, MF444329*, KU216817, KU234957, KU235072; O. squarrosus, Od30, h, Bolliger O-104 (P06137723), Spain, MF444532*, MF444355*, KU216840, KU234948, KU235093; Od73, h, Faure s.n. (E00247551), Algeria, - , - KU216820, KU234958, -; Od76, h, Smythies 1287 (E00247553), Spain, MF444537*, MF444359*, KU216841, KU234951, KU235091; Od77, h, Gardner 4745 (E00094635), Spain, MF444533*, MF444360*, KU216842, KU234949, KU235092; Od100, h, Walter 6 (B100271794), Tunisia, —, 一, KU216818, KU234959, 一; Od101, h, Walter 6 (B100271794), Tunisia, MF444534*, MF444356*, KU216819, KU234960, KU235089; Od105, h, Smythies s.n (RNG), Spain, MF444539*, MF444361*, KU216839, KU234952, KU235095; Od106, h, Smythies 2742 (RNG), Spain, MF444538*, MF444362*, KU216838, KU234953, KU235094; Od118, h, Hammada s.n. (RAB76180), Morocco, MF444535*, MF444357*, KU216843, KU234950, KU235090; Od174, s, Vela s.n. (P02439055), Tunisia, MF444536*, MF444358*, —, KU234973, KU235102; O. triboutii, Od61, s, Vela s.n. (P00685031), Algeria, MF444506*, MF444340*, KU216834, KU234936, KU235073; Od62, s, Vela s.n. (P00685031), Algeria, MF444507*, MF444341*, KU216835, KU234937, KU235074; Od90, s, Vela s.n. (P00685032), Algeria, MF444508*, MF444342*, KU216836, KU234938, KU235075; Od91, s, Vela s.n. (P00685032), Algeria, MF444509*, MF444343*, KU216837, KU234939, KU235076; Od146, s, Vela s.n. (-), Tunisia, MF444504*, MF444344*, KU216830, KU234946, KU235078; Od147, s, Vela s.n. (-), Tunisia, MF444505*, MF444345*, KU216831, KU234947, KU235077; O. vernus/vulgaris, Od41, s, Rouhan 734 (P00684968), France, MF444593*, MF444424*, KU216867, KU234898, KU235007; Od41B, s, Rouhan 734 (P00684968), France, MF444623*, MF444450*, MF444668*, MF444652*, MF444639*; Od50, s, Snogerup s.n. (P00685002), Denmark, MF444583*, MF444412*, KU216870, KU234907, KU235006; Od50B, s, Snogerup s.n. (P00685002), Denmark, MF444613*, MF444451*, MF444669*, MF444653*, MF444640*; Od51, s, Snogerup s.n. (P00685009), Sweden, MF444582*, MF444413*, KU216871, KU234895, KU234999; Od51B, s, Snogerup s.n. (P00685009), Sweden, MF444614*, MF444452*, MF444670*, MF444654*, MF444641*; Od52, s, Squirrell s.n. (-), England, MF444587*, MF444417*, KU216872, KU234894, KU235008; Od75, h, Gogina s.n. (E00247552), Russia, MF444588*, MF444418*, KU216876, KU234911, KU234997; Od122, s, Gaudeul 43 (P00577560), Morocco, MF444590*, MF444422*, KU216880, KU234887, KU235009; Od123, s, Gaudeul 43 (P00577560), Morocco, MF444591*, MF444423*, KU216879, KU234888, KU235010; Od137, h, Duthie 12088 (E00247555), India, 一, MF444421*, KU216861, KU234912, —; Od150, h, Schneeweiss 8543 (WU028735), Georgia, MF444594*, MF444425*, KU216860, KU234913, KU235011; Od154, h, Smith 270 (UPS-V159484), China, MF444589*, MF444419*, KU216862, KU234901, KU234996; Od155, h, Lao Chin 8091(UPS-V159455), China, MF444592*, MF444420*, KU216865, KU234902, KU234998; Od181, s, Snogerup s.n. (P00685011), Sweden, MF444619*, MF444442*, MF444671*, MF444655*, MF444642*; Od182, s, Snogerup s.n. (P00685011), Sweden, MF444615*, MF444443*, MF444672*, MF444656*, MF444643*; Od183, s, Snogerup s.n. (P00685017), Sweden, MF444620*, MF444444*, MF444673*, MF444657*, MF444644*; Od184, s, Snogerup s.n. (P00685017), Sweden, MF444621*, MF444445*, MF444674*, MF444658*, MF444645*; Od185, s, Snogerup s.n. (P00685026), Sweden, MF444618*, MF444446*, MF444675*, MF444659*, MF444646*; Od186, s, Snogerup s.n. (P00685026), Sweden, MF444617*, MF444447*, MF444676*, MF444660*, MF444647*; Od189, s, Gaudeul 6 (P00695930), France, MF444622*, MF444448*, MF444677*, MF444661*, MF444648*; Od191, s, Gaudeul 115 (P00696088), France, MF444616*, MF444449*, MF444678*, MF444662*, MF444649*; O. violaceus, Od132, h, Maurel s.n. (MPU011644), Algeria, MF444528*, MF444351*, KU216771, KU234940, KU235084; Od143, s, Vela s.n. (P00685035), Algeria, MF444529*, MF444352*, KU216827, KU234944, KU235081; Od144, s, Vela s.n. (P00685035), Algeria, MF444530*, MF444353*, KU216828, KU234943, KU235080; Od145, s, Vela s.n. (P00685036), Algeria, MF444531*, MF444354*, KU216829, KU234945, KU235079; O. viscosus, Od1, h, - (P06137732), Spain, MF444492*, MF444312*, KU216794, KU234914, —; Od2, h, — (P06137731), Spain, MF444493*, MF444313*, KU216802, KU234918, —; Od3, h, — (P06137730), Spain, MF444496*, MF444317*, KU216798, KU234919, —; Od4, h, — (P06137729), Spain, MF444497*, 
MF444318*, KU216803, KU234920, —; Od8, h, Bolliger O-108 (P06137726), Spain, MF444498*, MF444320*, KU216804, KU234921, KU235062; Od9, h, Bolliger O-108 (P06137725), Spain, MF444499*, MF444319*, KU216805, KU234922, —; Od10, h, Alejandre s.n. (P), Spain, MF444484*, MF444308*, KU216799, KU234923, 一; Od33, h, Alejandre O-129 (P06137722), Spain, MF444490*, MF444304*, KU216806, KU234924, KU234993; Od34, h, Alejandre O-133 (P), Spain, MF444485*, MF444305*, KU216807, KU234925, -; Od35, h, Bolliger O-100 (P06137721), Spain, MF444486*, MF444306*, KU216808, KU234926, —; Od36, s, Douzet s.n. (-), France, MF444487*, MF444307*, KU216795, KU234915, —; Od38, h, Bolliger O-138 (P06137715), Italy, MF444488*, MF444309*, KU216791, KU234916, 一; Od39, h, Bolliger O-2 (P06137714), Switzerland, MF444489*, MF444310*, KU216796, KU234917, —; Od42, h, Bolliger O-164 (P06137710), Morocco, MF444494*, MF444314*, KU216809, KU234927, —; Od56, s, Vela s.n. (P00684963), France, MF444491*, MF444311*, KU216792, KU234928, —; Od117, h, Bolliger O-150 (P06137718), Spain, —, MF444316*, KU216797, KU234929, —; Od119, h, Bolliger O-164 (P06137710), Morocco, MF444495*, MF444315*, KU216801, KU234930, —; Od127, s, Gaudeul 54 (P00577544), Morocco, MF444500*, MF444321*, KU216800, KU234931, KU235063; Od128, s, Gaudeul 64 (P00577565), Morocco, MF444501*, MF444322*, KU216793, KU234932, KU235064; Od129, h, Raynaud s.n. (RAB40773), Morocco, MF444502*, - , - -, 一; O. vulcanicus, Od134, h, Bolliger O-M3 (G00015046), Morocco, MF444527*, MF444336*, KU216845, KU234846, KU235065; Bartsia alpina, Od173, s, Rouhan 975 (P00577714), France, MF444626*, MF444462*, KU216903, KU234967, KU235096; Od70, s, Rouhan 732 (P00684965), France, MF444632*, MF444461*, KU216786, KU234820, KU234992; Bartsiella rameauana, Od136, h, Spence S.58 (E00247550), Morocco, MF444503*, MF444323*, KU216787, KU234855, -; Bellardia trixago, Od112, h, Peris \& Stübing s.n. (P), Spain, MF444633*, MF444455*, KU216785, KU234823, KU234991; Bornmuellerantha aucheri, Od113, h, Rechinger 32678 (M0142404), Azerbaijan, MF444544*, MF444380*, KU216902, KU234854, KU234994; Od13, h, Bornmüller 7881 (P06137724), Iran, MF444541*, MF444377*, KU216901, KU234852, 一; Od96, h, Strid 24119 (B100271788), Turkey, MF444542*, MF444378*, KU216774, KU234853, KU235022; Od97, h, Davis 9791 (B100271789), Lebanon, MF444543*, MF444379*, KU216900, KU234851, KU235023; Euphrasia sp., Od71, s, Gaudeul 1 (P00695917), France, MF444629*, 一, KU216779, KU234818, KU234976; E. tatarica, Od111, h, Markgraf s.n. (P06137719), Switzerland, MF444630*, MF444463*, KU216780, KU234819, KU234977; Lathraea clandestina, —, , , Chase 2605 (K), —, AY911230, —, —, —, —; L. squamaria, Od108, h, Authier 5837 (P06137711), Greece, MF444625*, MF444460*, KU216776, KU234964, —; Od177, s, Rouhan 1 (P00577589), France, -, MF444465*, - - - - - - - -, Italy, AM503877, -, -, -, 一; Macrosyringion glutinosum, Od16, s, Douzet s.n. (-), France, MF444545*, MF444295*, KU216760, KU234828, KU234983; Od94, h, Höltz s.n. (GOET), Turkey, MF444546*, MF444296*, KU216757, KU234829, KU234984; Od95, h, Vihodcevsky s.n. (GOET), Bulgaria, MF444547*, MF444297*, KU216758, KU234830, KU234985; Od98, h, Bergmeier 4139 (B100271790), Greece, Crete, MF444548*, MF444298*, KU216756, KU234831, -; Od99, h, Kocev s.n. (B100271791), Bulgaria, MF444549*, MF444299*, KU216759, KU234832, KU234982; M. longiflorum, Od103, h, Goyder 370 (RNG), Spain, MF444552*, MF444302*, KU216753, KU234826, KU234987; Od104, h, Goyder 444 (RNG), Spain, MF444553*, MF444303*, KU216754, KU234827, KU234988; Od12, h, Ern 3767 (P04036378), Spain, MF444550*, MF444300*, KU216755, KU234824, KU234989; Od83, h, Diez s.n. (E00247558), Spain, MF444551*, MF444301*, KU216752, KU234825, KU234986; Melampyrum nemorosum, Od72, s, Rouhan s.n. (P00685038), France, MF444634*, MF444466*, KU216775, KU234816, KU234978; Odontitella virgata, Od114, h, Merxmüller 21696 (M0142411), Spain, MF444467*, MF444457*, KU216783, KU234833, KU234980; Od115, h, Segura Zubizarreta 17395 (M0142414), Spain, MF444468*, MF444458*, KU216782, KU234834, KU234981; Od116, h, Merxmüller 785/62 (M0142409), Spain, MF444469*, 一, KU216781, KU234835, KU234979; Parentucellia latifolia, Od109, h, Ramos Lopes 101 (P03934294), Portugal, MF444628*, MF444453*, KU216810, KU234821, —; P. viscosa, Od110, h, Legros s.n. (P06137720), France, MF444631*, MF444454*, KU216811, KU234822, —; Rhinantus sp., Od159, s, Gaudeul 29 (P00695973), France, MF444627*, MF444456*, KU216778, KU234965, KU234975; Rhynchochorys maxima, Od151, h, Roques 8523 (P06137717), Iran, —, MF444459*, KU216777, KU234815, -; -, 一, Albach \& Schneeweiss 21 Aug. 2000 (WU), —, AY911251, —, 一, -, 一; Tozzia alpina, Od152, h, Aymonin 23596 (P06137716), France, —, 一, MF444679*, MF444663*, —; Od153, h, Rivas-Martinez s.n. (P), Spain, —, —, KU216784, KU234817, —; Od178, s, Rouhan 1110 (P00750152), France, MF444624*, MF444464*, —, —, 一; 一, —, Wetschnig s.n. (PAC), 一, AY911258, 一, 一, 一, 一;

\section{Appendix B}

\section{Voucher Information for Samples Measured for Nuclear Genome Size}

Species, population (number of individuals measured), voucher (herbarium barcode). Herbarium acronyms follow Thiers (2017).

Odontites bocconii, Pop. 1 (2 ind.), Certa s.n. (PAL90580); Pop. 2 (2 ind.), Domina s.n. (PAL90581); O. cebennensis, Pop. 1 (2 ind.), Gaudeul 14 (P00695946); Pop. 2 (2 ind.), Leblond s.n. (P00685030); Pop. 3 (2 ind.), Gaudeul 12 (P00695943); O. corsicus, Pop. 1 (4 ind.), Rouhan 1108 (P00695915); O. discolor, Pop. 1 (4 ind.), Vela s.n. (P00685037); O. hispidulus, Pop. 1 (4 ind.), Bou Dagher-Kharrat s.n. (P02433311); O. hollianus, Pop. 1 (2 ind.), Gaudeul 105 (P00696073); Pop. 2 (1 ind.), Gaudeul 106 (P00696076); Pop. 3 (1 ind.), Gaudeul 107 (P00696077); O. jaubertianus, Pop. 1 (3 ind.), Gaudeul 110 (P00696081); Pop. 2 (2 ind.), Gaudeul 118 (P00696092); Pop. 3 (2 ind.), Gaudeul 2 (P00695918); Pop. 4 (1 ind.), Gaudeul 4 (P00695924); O. lanceolatus, Pop. 1 (2 ind.), Gaudeul 74 (P00696025); Pop. 2 (2 ind.), Gaudeul 70 (P00696007); Pop. 3 
(1 ind.), Gaudeul 76 (P00696030); Pop. 4 (1 ind.), Douzet s.n. (-); O. linkii, Pop. 1 (3 ind.), Gücel s.n. (-); Pop. 2 (2 ind.), Gücel s.n. (-); O. litoralis, Pop. 1 (4 ind.), Christenhusz 4495 (P00598561); Pop. 2 (2 ind.), Pankhurst 07/46 (E00314994); Pop. 3 (1 ind.), Pankhurst 07/43 (E00314995); O. luteus, Pop. 1 (3 ind.), Tribsch 4651 (P00684961); Pop. 2 (2 ind.), Gaudeul 13 (P00695944); Pop. 3 (2 ind.), Douzet s.n. (-); Pop. 4 (2 ind.), Rouhan 733 (P00684966); Pop. 5 (1 ind.), Rouhan 1098 (P00695904); Pop. 6 (1 ind.), Gaudeul 84 (P00696043); Pop. 7 (1 ind.), Gaudeul 112 (P00696085); O. maroccanus, Pop. 1 (7 ind.), Gaudeul 40 (P00577538); O. powellii, Pop. 1 (3 ind.), Gaudeul 50 (P00577543); Pop. 2 (2 ind.), Gaudeul 41 (P00577539); Pop. 3 (1 ind.), Gaudeul 39 (P00577550); Pop. 4 (1 ind.), Gaudeul 66 (P00696004); O. pyrenaeus, Pop. 1 (2 ind.), Gaudeul 16 (P00695948); Pop. 2 (2 ind.), Gaudeul 27 (P00695971); O. recordonii, Pop. 1 (3 ind.), Gaudeul 20 (P00695956); Pop. 2 (2 ind.), Gaudeul 22 (P00695959); O. squarrosus, Pop. 1 (4 ind.), Vela s.n. (P02439055); O. triboutii, Pop. 1 (5 ind.), Vela s.n. (P00685033); Pop. 2 (3 ind.), Vela s.n. (-); Pop. 3 (3 ind.), Vela s.n. (P00685032); Pop. 4 (2 ind.), Vela s.n. (P00685034); O. vernus/vulgaris (small genome), Pop. 1 (2 ind.), Gaudeul 111 (P00696083); Pop. 2 (1 ind.), Gaudeul 8 (P00695932); Pop. 3 (1 ind.), Squirrell s.n. (-); Pop. 4, Gaudeul 10 (P00695939); Pop. 5, Domina s.n. (PAL88461); Pop. 6 (1 ind.), Gaudeul 43 (P00577560); Pop. 7, Squirrell s.n. (-); Pop. 8, Bourguignon s.n. (P00684990); Pop. 9, Snogerup s.n. (P00685017); Pop. 10, Tribsch 4650 (P00684962); Pop. 11, Gaudeul 120 (P00696095); Pop. 12, Delahaye s.n. (P00684984); Pop. 13, Snogerup s.n. (P00685026); Pop. 14, Gaudeul 108 (P00696078); Pop. 15, Snogerup s.n. (P00685011); Pop. 16, Gaudeul 119 (P00696094); O. vernus/vulgaris (large genome), Pop. 1 (1 ind.), Rouhan 734 (P00684968); Pop. 2 (1 ind.), Snogerup s.n. (P00685002); Pop. 3 (1 ind.), Snogerup s.n. (P00685009); Pop. 4 (1 ind.), Gaudeul 6 (P00695930); Pop. 5 (1 ind.), Gaudeul 115 (P00696088); O. violaceus, Pop. 1 (3 ind.), Vela s.n. (P00685035); Pop. 2 (2 ind.), Vela s.n. (P00685036); O. viscosus, Pop. 1 (3 ind.), Gaudeul 90 (P00696051); Pop. 2 (1 ind.), Delahaye s.n. (P00684971); Pop. 3 (1 ind.), Gaudeul 64 (P00577565); Pop. 4 (1 ind.), Gaudeul 54 (P00577544); Pop. 5 (1 ind.), Douzet s.n. (-); Pop. 6 (1 ind.), Gaudeul 19 (P00695954).

\section{Acknowledgments}

We thank all people who collected leaf and seed material in the field: S. Aubert, J. Blanchemain, M. Bou Dagher-Kharrat, V. Bourguignon, G. Certa, M. Christenhusz, T. Delahaye, G. Domina, R. Douzet, B. Frajman, M. Gardner, S. Gücel, P. Lacosse, S. Leblond, R. Pankhurst, M.-J. Rouhan, E. Schmitt, P. Schönswetter, B. Snogerup, J. Squirrell, G. Tohmé, T. Aadel, and A. Tribsch. We also thank the curators of the following herbaria, who allowed sampling material on dried specimens: E, G, GOET, INA Alger, M, MPU, RAB, RNG, UPS, and WU. We are grateful to the Algerian, French, Madeiran, and Moroccan authorities for granting collecting permits and to J. El Oualidi and M. Fennane (University Mohammed V-Agdal, Rabat, Morocco) for their logistical support in the field. We gratefully acknowledge M. Bourge and S. Brown for their assistance with flow cytometry measurements at the Imagif platform, C. Raquin for help with seed germination, and $\mathrm{H}$. Weiss-Schneeweiss and two anonymous reviewers for very helpful comments on the manuscript. We acknowledge funding from the Action Transversales du MuséumMuséum National d'Histoire Naturelle (MNHN) "Structure et évolution des écosystèmes" and "Taxonomie moléculaire, DNA barcode et gestion durable des collections." This project was also supported by the network Bibliothèque du Vivant funded by the Centre National de la Recherche Scientifique, the MNHN, the Institut National de la Recherche Agronomique, and the Centre National de Séquençage. All molecular work was performed at the Botany-Entomology-Mycology laboratory of the MNHN.

\section{Literature Cited}

Abbott R, D Albach, S Ansell, JW Arntzen, SJE Baird, N Bierne, J Boughman, et al 2013 Hybridization and speciation. I Evol Biol 26:229-246.

Alvarez I, JF Wendel 2003 Ribosomal ITS sequences and plant phylogenetic inference. Mol Phylogenet Evol 29:417-434.

Baldwin BG, S Markos 1998 Phylogenetic utility of the external transcribed spacer (ETS) of 18S-26S rDNA: congruence of ETS and ITS trees of Calycadenia (Compositae). Mol Phvlogenet Evol 10:449-463.

Beardsley PM, RG Olmstead 2002 Redefining Phrymaceae: the placement of Mimulus, tribe Mimuleae and Phryma. Am I Bot 89:10931102.

Blanco-Pastor JL, P Vargas, BE Pfeil 2012 Coalescent simulations reveal hybridization and incomplete lineage sorting in Mediterranean Linaria. PLoS ONE 7:e39089.

Bolliger M 1996 Monographie der Gattung Odontites (Scrophulariaceae) sowie der verwandten Gattungen Macrosyringion, Odontitella, Bornmullerantha und Bartsiella. Willdenowia 26:37-168.

Crespo MB, G Mateo Sanz 2009 Odontites valentinus sp. nov. (Scrophulariaceae): a new endemic taxon from eastern Spain. Flora Montiberica 41:62-66.
Delgado L, D Pinto Carrasco, F Gallego Martin, E Rico 2015 Contribution to the karyological knowledge of Odontites s.l. (Orobanchaceae) on the Iberian Peninsula and in Morocco. Folia Geobot 50:63-74.

de Queiroz K 2007 Species concepts and species delimitation. Syst Biol 56:879-886.

Dönmez A, B Mutlu 2010 Bornmuellerantha alshehbaziana (Orobanchaceae), a new species from Turkey. Novon 20:265-267.

Edgar RC 2004 MUSCLE: multiple sequence alignment with high accuracy and high throughput. Nucleic Acids Res 32:1792-1797.

Escudero M, E Maguilla, J Loureiro, M Castro, S Castro, M Luceno 2015 Genome size stability despite high chromosome number variation in Carex gr. laevigata. Am I Bot 102:233-238.

Escudero M, S Martin-Bravo, I Mayrose, M Fernandez-Mazuecos, O Fiz-Palacios, AL Hipp, M Pimentel, et al 2014 Karyotypic changes through dysploidy persist longer over evolutionary time than polyploid changes. PLoS ONE 9:e85266.

Farris JS, M Källersjo, AG Kluge, C Bult 1995 Constructing a significance test for incongruence. Syst Biol 44:570-572.

Frajman B, B Oxelman 2007 Reticulate phylogenetics and phytogeographical structure of Heliosperma (Sileneae, Caryophyllaceae) in- 
ferred from chloroplast and nuclear sequences. Mol Phvlogenet Evol 43:140-155.

Frajman B, I Resetnik, H Weiss-Schneeweiss, F Ehrendorfer, P Schönswetter 2015 Cytotype diversity and genome size variation in Knautia (Caprifoliaceae, Dipsacoideae). BMC Evol Biol 15:140.

Freudenstein JV 1998 Paraphyly, ancestors and classification-a response to Sosef and Brummitt. Taxon 47:95-104.

Galbraith DW, KR Harkins, JM Maddox, NM Ayres, DP Sharma, E Firoozabady 1983 Rapid flow cytometric analysis of the cell cycle in intact plant tissues. Science 220:1049-1051.

Gaudeul M, E Véla, G Rouhan 2016 Eastward colonization of the Mediterranean Basin by two geographically structured clades: the case of Odontites Ludw. (Orobanchaceae). Mol Phylogenet Evol 96:140-149.

Hall TA 1999 BioEdit: a user-friendly biological sequence alignment editor and analysis program for Windows 95/98/NT. Nucleic Acids Symp Ser 41:95-98.

Hewitt GM 2004 Genetic consequences of climatic oscillations in the Quaternary. Philos Trans R Soc B 359:183-195.

Howarth DG, DA Baum 2005 Genealogical evidence of homoploid hybrid speciation in an adaptive radiation of Scaevola (Goodeniaceae) in the Hawaiian Islands. Evolution 59:948-961.

Koutecky P, G Tuleu, T Badurova, J Kosnar, M Stech, J Tesitel 2012 Distribution of cytotypes and seasonal variation in the Odontites vernus group in central Europe. Preslia 84:887-904.

Linder CR, LH Rieseberg 2004 Reconstructing patterns of reticulate evolution in plants. Am I Bot 91:1700-1708.

Mallet J 2007 Hybrid speciation. Nature 446:279-283.

Marie D, SC Brown 1993 A cytometric exercise in plant DNA histograms, with 2C values for seventy species. Biol Cell 78:41-51.

Marie Curie SPECIATION Network 2012 What do we need to know about speciation? Trends Ecol Evol 27:27-39.

Mitsui Y, S-T Chen, Z-K Zhou, G-I Peng, Y-F Deng, H Setoguchi 2008 Phylogeny and biogeography of the genus Ainsliaea (Asteraceae) in the Sino-Japanese region based on nuclear rDNA and plastid DNA sequence data. Ann Bot Lond 101:111-124.

Müller K 2005 SeqState: primer design and sequence statistics for phylogenetic DNA data sets. Appl Bioinform 4:65-69.

Niketic M, S Siljak-Yakovlev, B Frajman, M Lazarevic, B Stevanovic, G Tomovic, V Stevanovic 2013 Towards resolving the systematics of Cerastium subsection Cerastium (Caryophyllaceae): a cytogenetic approach. Bot I Linn Soc 172:205-224.

Nolte AW, D Tautz 2010 Understanding the onset of hybrid speciation. Trends Ecol Evol 26:54-58.

Nylander JAA 2004 MrModeltest, version 2. Evolutionary Biology Centre, Uppsala University, Uppsala, Sweden.

Ottonello D, S Romano, N Alliata 1985 Numeri cromosomici per la flora Italiana: 1037-1048. Inf Bot Ital 17:91-98.

Pellicer J, S Clermont, L Houston, TCG Rich, MF Fay 2012 Cytotype diversity in the Sorbus complex (Rosaceae) in Britain: sorting out the puzzle. Ann Bot Lond 110:1185-1193.

Pellicer J, LJ Kelly, C Magdalena, IJ Leich 2013 Insights into the dynamics of genome size and chromosome evolution in the early diverging angiosperm lineage Nymphaeales (water lilies). Genome 56: 437-449.

Rambaut A, MA Suchard, D Xie, AJ Drummond 2014 Tracer, version 1.6. Accessed April 6, 2017. http://beast.bio.ed.ac.uk/Tracer.

Razafinarivo NJ, J-J Rakotomalala, SC Brown, M Bourge, S Hamon, A de Kochko, V Poncet, et al 2012 Geographical gradients in the genome size variation of wild coffee tree (Coffea) native to Africa and Indian Ocean islands. Tree Genet Genomes 8:1345-1358.

Rico E 2009 Odontites Ludw.; Odontitella Rothm.; Macrosyringion Rothm. Pages 473-501 in C Benedi, E Rico, J Güemes, A Herrero, eds. Flora Iberica. Vol 13. Plantaginaceae-Scrophulariaceae. CSIC, Madrid.
Rico E, L Delgado, A Herrero 2008 Reassessing the Odontites purpureus group (Orobanchaceae) from south-east Spain and northwest Africa. Bot I Linn Soc 158:701-708.

Rieseberg LH 1997 Hybrid origins of plant species. Annu Rev Ecol Syst 28:359-389.

Rockinger A, A Sousa, FA Carvalho, SS Renner 2016 Chromosome number reduction in the sister clade of Carica papaya with concomitant genome size doubling. Am I Bot 103:1082-1088.

Ronquist F, M Teslenko, P van der Mark, D Ayres, A Darling, S Hohna, B Larget, et al 2011 MrBayes 3.2: efficient Bayesian phylogenetic inference and model choice across a large model space. Syst Biol 61:539-542.

Scheunert A, A Fleischmann, C Olano-Marin, C Bräuchler, G Heubl 2012 Phylogeny of tribe Rhinantheae (Orobanchaceae) with a focus on biogeography, cytology and re-examination of generic concepts. Taxon 61:1269-1285.

Seehausen O 2004 Hybridization and adaptive radiation. Trends Ecol Evol 19:198-207.

Silvestro D, I Michalak 2012 raxmlGUI: a graphical front-end for RAxML. Org Divers Evol 12:335-337.

Simmons MP, H Ochoterena 2000 Gaps as characters in sequencebased phylogenetic analyses. Syst Biol 49:369-381.

Snogerup B 1977 Chromosome numbers of Scandinavian Odontites species. Bot Not 130:121-124.

Soltis DE, EV Mavrodiev, JJ Doyle, J Rauscher, PS Soltis 2008 ITS and ETS sequence data and phylogeny reconstruction in allopolyploids and hybrids. Syst Bot 33:7-20.

Soltis PS, DE Soltis 2009 The role of hybridization in plant speciation. Annu Rev Plant Biol 60:561-588.

Stamatakis A 2014 RAxML version 8: a tool for phylogenetic analysis and post-analysis of large phylogenies. Bioinformatics 30:13121313.

Suda J, P Travnicek 2006 Reliable DNA ploidy determination in dehydrated tissues of vascular plants by DAPI flow cytometry- new prospects for plant research. Cytom A 69:273-280.

Swofford DL 2002 PAUP*: phylogenetic analysis using parsimony (*and other methods), version 4. Sinauer, Sunderland, MA.

Talent N, TA Dickinson 2005 Polyploidy in Crataegus and Mespilus (Rosaceae, Maloideae): evolutionary inferences from flow cytometry of nuclear DNA amounts. Can I Bot 83:1268-1304.

Tesitel J, P Riha, S Svobodova, T Malinova, M Stech 2010 Phylogeny, life history evolution and biogeography of the Rhinanthoid Orobanchaceae. Folia Geobot 45:347-367.

Thiers B 2017 Index Herbariorum: a global directory of public herbaria and associated staff. http://sweetgum.nybg.org/ih/.

Thompson JD 2005 Plant evolution in the Mediterranean. Oxford University Press, Oxford.

Valente LM, V Savolainen, P Vargas 2010 Unparalleled rates of species diversification in Europe. Proc R Soc Lond B 277:1489-1496.

Van der Niet T, HP Linder 2008 Dealing with incongruence in the quest for the species tree: a case study from the orchid genus $\mathrm{Sa}$ tyrium. Mol Phylogenet Evol 47:154-174.

Vriesendorp B, FT Bakker 2005 Reconstructing patterns of reticulate evolution in angiosperms: what can we do? Taxon 54:593-604.

Weiss-Schneeweiss H, C Blöch, B Turner, JL Villarsenor, TF Stuessy, GM Schneeweiss 2012 The promiscuous and the chaste: frequent allopolyploid speciation and its genomic consequences in American daisies (Melampodium sect. Melampodium; Asteraceae). Evolution 66:211-228.

Weiss-Schneeweiss H, K Emadzade, T-S Jang, GM Schneeweiss 2013 Evolutionary consequences, constraints and potential of polyploidy. Cytogenet Genome Res 140:137-150.

Weiss-Schneeweiss H, J Greilhuber, GM Schneeweiss 2006 Genome size evolution in holoparasitic Orobanche (Orobanchaceae) and related genera. Am I Bot 93:148-156. 
Weiss-Schneeweiss H, GM Schneeweiss 2013 Karyotype diversity and evolutionary trends in angiosperms. Pages 209-230 in IJ Leitch, J Greilhuber, J Dolezel, JF Wendel, eds. Plant genome diversity. Vol 2. Springer, Wien, Austria.

White TJ, T Bruns, S Lee, J Taylor 1990 Amplification and direct sequencing of fungal ribosomal RNA genes for phylogenetics. Pages 315322 in MA Innis, DH Gelfand, JJ Sninsky, TJ White, eds. PCR protocols: a guide to methods and applications. Academic Press, San Diego, CA.
Wood TE, N Takebayashi, MS Barker, I Mayrose, PB Greenspoon, LH Rieseberg 2009 The frequency of polyploid speciation in vascular plants. Proc Natl Acad Sci USA 106:13875-13879.

Wu J, T Nyman, D-C Wang, GW Argus, Y-P Yang, J-H Chen 2015 Phylogeny of Salix subgenus Salix s.l. (Salicaceae): delimitation, biogeography, and reticulate evolution. BMC Evol Biol 15:31.

Yi T, J Wen, A Golan-Goldhirsh, DE Parfitt 2008 Phylogenetics and reticulate evolution in Pistacia (Anacardiaceae). Am I Bot 95:241251. 